\title{
Preparation and Comprehensive Characterization of a Calcium Hydroxyapatite Reference Material
}

\section{Milenko Markovic}

American Dental Association

Foundation,

Paffenbarger Research Center,

National Institute of Standards and Technology,

Gaithersburg, MD 20899, USA

\section{Bruce O. Fowler}

National Institute of Dental and Craniofacial Research, NIH, Craniofacial and Skeletal Diseases Branch Research Associate Program at the National Institute of Standards and Technology,

Gaithersburg, MD 20899, USA

and

Ming S. Tung

American Dental Association

Foundation,

Paffenbarger Research Center, National Institute of Standards and Technology,

Gaithersburg, MD 20899, USA
Numerous biological and chemical studies involve the use of calcium hydroxyapatite (HA), $\mathrm{Ca}_{10}\left(\mathrm{PO}_{4}\right)_{6}(\mathrm{OH})_{2}$. In this study detailed physicochemical characterization of HA, prepared from an aqueous solution, was carried out employing different methods and techniques: chemical and thermal analyses, $\mathrm{x}$-ray diffraction, infrared and Raman spectroscopies, scanning and transmission microscopies, and Brunauer, Emmett, and Teller (BET) surface-area method. The contents of calcium $\left(\mathrm{Ca}^{2+}\right)$, phosphate $\left(\mathrm{PO}_{4}^{3}\right)$, hydroxide $(\mathrm{OH})$, hydrogenphosphate $\left(\mathrm{HPO}_{4}^{2}\right)$, water $\left(\mathrm{H}_{2} \mathrm{O}\right)$, carbonate $\left(\mathrm{CO}_{3}{ }^{2}\right)$, and trace constituents, the $\mathrm{Ca} / \mathrm{P}$ molar ratio, crystal size and morphology, surface area, unit-cell parameters, crystallinity, and solubility of this HA were determined. This highly pure, homogeneous, and highly crystalline HA is certified as a National Institute of Standards and Technology (NIST) standard reference material, SRM 2910.
Key words: chemical analysis; crystal size; crystallinity; hydroxyapatite; infrared; morphology; preparation; Raman; solubility; surface area; thermal analysis; unit-cell parameters; $x$-ray diffraction.

Accepted: November 11, 2004

Available online: http://www.nist.gov/jres

\section{Introduction}

Calcium hydroxyapatite (HA), $\mathrm{Ca}_{10}\left(\mathrm{PO}_{4}\right)_{6}(\mathrm{OH})$, is an important inorganic material in biology and chemistry [1-3]. Biological apatites, which are the inorganic constituents of bone, tooth enamel and dentin, are typ- ically very variable in their composition and morphology, and contain different impurities $\left(\mathrm{Mg}^{2+}, \mathrm{K}^{+}, \mathrm{Na}^{+}\right.$, $\mathrm{CO}_{3}^{2-}, \mathrm{HPO}_{4}^{2-}, \mathrm{Cl}^{-}, \mathrm{F}^{-}$, etc.) [1]. In general, these impure biological apatites are designated as calcium deficient or non-stoichiometric apatites. 
Synthetic HAs are frequently used as reference materials in biomineralization and biomaterial studies. The composition, physicochemical properties, crystal size and morphology of synthetic apatites are extremely sensitive to preparative conditions. Common impurity phases in synthetic apatites prepared by precipitation from supersaturated aqueous solutions are calcium phosphate compounds such as amorphous calcium phosphates (ACP) with variable compositions of $\mathrm{Ca}_{3}\left(\mathrm{PO}_{4}\right)_{2-2 x}\left(\mathrm{HPO}_{4}\right)_{3 x} \cdot n \mathrm{H}_{2} \mathrm{O}$, octacalcium phosphate (OCP), $\mathrm{Ca}_{8}\left(\mathrm{HPO}_{4}\right)_{2}\left(\mathrm{PO}_{4}\right)_{4} \cdot 5 \mathrm{H}_{2} \mathrm{O}$, and calcium hydrogenphosphate dihydrate (DCPD), $\mathrm{CaHPO}_{4} \cdot 2 \mathrm{H}_{2} \mathrm{O}$. In addition, the incorporation of various ions as trace impurities (hydrogenphosphate, carbonate, silicate ions, etc.) is very difficult to prevent in any preparative procedure of HA [3].

For control and reference purposes, it is important to have available pure and stoichiometric HA, or nearly stoichiometric HA, characterized in detail with respect to its chemical composition and numerous other important properties. To meet this need, a large amount of highly pure, homogeneous and highly crystalline HA was synthesized by precipitation from aqueous solution of calcium hydroxide and phosphoric acid and then rigorously characterized by chemical and thermal analyses, infrared (IR) and Raman spectroscopies, powder xray diffraction (XRD), scanning and transmission microscopies, and surface area and solubility product [4] measurements. The chemical composition and other analyzed properties of this HA qualify it as a standard reference material (NIST, SRM 2910) [5] and it is hereafter denoted as HA-SRM.

Synthetic HA occurs in two structural forms, hexagonal and monoclinic, which have minor structural differences [2]. The hexagonal HA form is usually formed by precipitation from supersaturated solutions at $25^{\circ} \mathrm{C}$ to $100{ }^{\circ} \mathrm{C}$ and the monoclinic form of $\mathrm{HA}$ is primarily formed by heating the hexagonal form at $850{ }^{\circ} \mathrm{C}$ in air and then cooling to room temperature [6]. The overall XRD patterns of hexagonal and monoclinic HA are almost identical; however the pattern of monoclinic HA has additional weak lines whose intensities are less than $1 \%$ of the strongest hexagonal HA line [7]. The HA-SRM analyzed here is composed of the hexagonal form (mass fraction of about $75 \%$ ) and of the monoclinic form (mass fraction of about $25 \%$ ) as determined by normalized additional XRD measurements of the weak line of monoclinic HA at $2 \theta=36.28^{\circ}$ [6-8]. Only the hexagonal form, the major component in HA-SRM, is discussed in this paper. Preparation and characterization of the monoclinic form of $\mathrm{HA}$ and dif- ferences between the hexagonal and monoclinic HA will be discussed in a separate paper [8].

\section{Experimental Section}

\subsection{Preparation}

Calcium hydroxyapatite-standard reference material (HA-SRM) was synthesized by solution reaction of calcium hydroxide and phosphoric acid in accordance with the preparation of McDowell et al. [9]. In brief, about $5 \mathrm{~L}$ of distilled water was boiled for $60 \mathrm{~min}$ in a 7.5 L Teflon-coated pot equipped with an electric stirring paddle, a reflux condenser with a $\mathrm{CO}_{2}$-absorbing $\mathrm{NaOH}$ trap to protect from atmospheric $\mathrm{CO}_{2}$, and ports for introducing titrant and nitrogen gas. Calcium oxide (prepared from calcium carbonate heated for $3 \mathrm{~h}$ at $1100{ }^{\circ} \mathrm{C}$ ) was added to the water. Phosphoric acid (concentration $2 \mathrm{~mol} / \mathrm{L}$ ) was added to the calcium oxide/calcium hydroxide slurry at a rate of $0.3 \mathrm{~mL} / \mathrm{min}$ to 0.6 $\mathrm{mL} / \mathrm{min}$ and to a final $\mathrm{Ca} / \mathrm{P}$ molar ratio of 1.67 . The reacting mixture was boiled for $2 \mathrm{~d}$. The precipitated solid phase was allowed to settle, the supernatant decanted, and an equal volume of boiled distilled water was added. This suspension was boiled for another $2 \mathrm{~d}$. These washing and boiling procedures were repeated four times until the $\mathrm{pH}$ of the supernatant was $\approx 6$; at $\mathrm{pH}$ 6 , any possible traces of anhydrous dicalcium hydrogenphosphate (DCPA) are converted into HA. The precipitate, collected by filtration, was thoroughly washed with acetone, and then dried at $105^{\circ} \mathrm{C}$ for $1 \mathrm{~d}$. The yield was about $1 \mathrm{~kg}$.

\subsection{Characterization}

The HA-SRM was characterized using different methods and techniques. Twenty randomly selected samples were analyzed for both calcium and total phosphorus content. Four samples were analyzed for the content of phosphorus in the form of hydrogenphosphate $\left(\mathrm{HPO}_{4}{ }^{2-}\right)$. Fourteen samples were analyzed for water content. Twelve samples were analyzed for carbonate content. The contents of silicon and other trace constituents were determined in one sample. The specific surface area was determined on twelve samples. In addition, scanning and transmission electron microscopy (SEM and TEM), x-ray diffraction (XRD), and infrared (IR) and Raman spectroscopies were employed for detailed characterization. 


\subsection{Chemical Analyses}

\subsubsection{Calcium Content}

Calcium was determined by atomic absorption spectroscopy with a Perkin-Elmer Model 603 spectrophotometer ${ }^{1}$ using an air-acetylene flame and the $442.7 \mathrm{~nm}$ wavelength line. Standard calcium solutions used for calibration contained weighed amounts of calcium carbonate (NIST SRM 915, dried at $250^{\circ} \mathrm{C}$ for $2 \mathrm{~h}$ ) and $\mathrm{LaCl}_{3}$ in the concentration of about $4.08 \mathrm{mmol} / \mathrm{L}$ (about $1000 \mathrm{ppm})$. The calcium solutions were placed in volumetric flasks (Class A) having volume of $500 \mathrm{~mL} \pm 0.2 \mathrm{~mL}$ (later assumed as a standard uncertainty). For experimental details see Refs. [4] and [10].

\subsubsection{Phosphorus Content}

Phosphorus was determined colorimetrically [11] as the phosphovanadomolybdate complex with a Cary Model 219 spectrometer using a wavelength of $420 \mathrm{~nm}$. Standard phosphate solutions (flasks Class A with volume of $100 \mathrm{~mL} \pm 0.08 \mathrm{~mL}$ ) used for calibration contained weighed amounts of potassium dihydrogenphosphate (Baker Ultrex Reagent, dried at $105^{\circ} \mathrm{C}$ for $2 \mathrm{~h}$ ) and vanadomolybdate reagent. For experimental details see Refs. [4] and [10].

\subsubsection{Hydrogenphosphate Content}

The Gee and Deitz method [11] with some modifications [12] was used for determination of the content of phosphorus in the form of hydrogenphosphate $\left(\mathrm{HPO}_{4}{ }^{2-}\right)$ in HA. The HA-SRM sample was heated at $550{ }^{\circ} \mathrm{C}$ in air for $24 \mathrm{~h}$ to convert the hydrogenphosphate into pyrophosphate $\left(\mathrm{P}_{2} \mathrm{O}_{7}^{4}\right)$. One portion (A) of this heated sample $(\approx 9 \mathrm{mg})$ was dissolved in $1 \mathrm{~mol} / \mathrm{L} \mathrm{HClO}_{4}$ (in $100 \mathrm{~mL}$ volumetric flask) and heated in a boiling water bath for $3 \mathrm{~h}$ to hydrolyze the whole content of $\mathrm{P}_{2} \mathrm{O}_{7}{ }^{4}$ into phosphate ions $\left(\mathrm{PO}_{4}{ }^{3}\right)$. Another portion $(\mathrm{B})$ of heated HA-SRM $(\approx 9 \mathrm{mg})$ was freshly dissolved at $25^{\circ} \mathrm{C}$ just prior to phosphate analysis to minimize hydrolysis of $\mathrm{P}_{2} \mathrm{O}_{7}^{4-}$ to phosphates. The phosphorus concentrations were determined in both samples as described in Section 2.3.2. The difference in phosphorus contents between samples B and A corresponds to

\footnotetext{
${ }^{1}$ Certain commercial equipment, instruments or materials are identified in this paper to foster understanding. Such identification does not imply recommendation or endorsement by the National Institute of Standards and Technology, the National Institutes of Health, or the ADA Foundation nor does it imply that the materials or equipment identified are necessarily the best available for the purpose.
}

the content of $\mathrm{P}_{2} \mathrm{O}_{7}{ }^{4}$ in the heated HA-SRM and to the content of $\mathrm{HPO}_{4}{ }^{2-}$ in the unheated HA-SRM sample.

\subsubsection{Water Content}

The water content was determined from mass loss by three different procedures: (a) The thermogravimetric analysis (TGA) was performed on five samples all in the temperature range from $30^{\circ} \mathrm{C}$ to $850{ }^{\circ} \mathrm{C}$ (rate $10{ }^{\circ} \mathrm{C} / \mathrm{min}$ ) in a nitrogen atmosphere. (b) Six powdered samples (mass $200 \mathrm{mg}$ to $500 \mathrm{mg}$ ) were heated at $850{ }^{\circ} \mathrm{C}$ in air at $\approx 50 \%$ relative humidity for times ranging from $16 \mathrm{~h}$ to $20 \mathrm{~h}$. The samples were weighed after cooling for $5 \mathrm{~min}$ in a desiccator at ambient conditions. (c) Three of the powdered samples were pressed into pellets and heated at $1000{ }^{\circ} \mathrm{C}$ in a steam atmosphere $(100 \mathrm{kPa})$ for $10 \mathrm{~h}$. These samples were weighed after cooling for $5 \mathrm{~min}$ in a desiccator.

\subsubsection{Carbonate Content}

The carbonate $\left(\mathrm{CO}_{3}{ }^{2-}\right)$ content was determined by heating $\approx 5 \mathrm{~g}$ of the HA-SRM sample at $1200{ }^{\circ} \mathrm{C}$ to liberate $\mathrm{CO}_{2}$ that was collected in an absorption cell containing a lithium hydroxide solution. Carbonates in the absorption-cell were determined by automatic coulometric titration. These analyses were done by Galbraith Laboratories, Knoxville, TN.

\subsubsection{Silicate and Trace Elements Content}

The content of silicon and 63 other elements were analyzed by inductively coupled plasma mass spectroscopy (IPS-MS) by Galbraith Laboratories, Knoxville, TN.

\subsection{Transmission and Scanning Electron Microscopy}

Transmission electron micrographs were obtained from crystals placed directly onto formvar- and carboncoated nickel grids, or from crystals that were suspended in solution by brief sonication in pure ethanol. In the latter case, ethanol-suspended crystals were allowed to settle onto the support film after which the ethanol was extracted from the edges of the grid with filter paper. Ultrastructural images of the crystals were recorded by transmission electron microscopy at an accelerating voltage of $80 \mathrm{kV}$ using a JEOL JEM 2000FX-II. The samples for scanning electron microscopy were coated with gold and examined with a scanning electron microscope JEOL 5300. 


\subsection{Surface Area}

The surface area was determined by the triple-point BET (Brunauer, Emmett, Teller) method [13] with nitrogen as the adsorbate gas and helium as an inert non-adsorbable carrier. The mole fractions of nitrogen in $\mathrm{N}_{2} / \mathrm{He}$ flowing mixtures were $0.1,0.2$ and 0.3 . The sample mass was about $200 \mathrm{mg}$.

\subsection{Infrared Spectroscopy}

IR transmission and second derivative spectra were recorded with a Perkin-Elmer Model 621 spectrometer and with a Nicolet Magna 550 spectrometer, respectively, from the HA-SRM powder suspended in $\mathrm{KBr}$ pellets.

\subsubsection{IR Transmission Spectra}

IR transmission spectra from $4000 \mathrm{~cm}^{-1}$ to $300 \mathrm{~cm}^{-1}$ were recorded at $48{ }^{\circ} \mathrm{C}$ (temperature in instrument light beam) with a Perkin-Elmer Model 621 spectrometer purged with dry $\mathrm{CO}_{2}$-free air. $\mathrm{KBr}$ sample pellets were run versus a blank $\mathrm{KBr}$ pellet in the reference beam to cancel $\mathrm{KBr}$ impurity bands, mainly $\mathrm{H}_{2} \mathrm{O}$ bands. $\mathrm{KBr}$ pellets were prepared by mixing (not grinding) the pre ground HA-SRM $(0.8 \mathrm{mg}$ and $4.0 \mathrm{mg}$; particle cluster size $\leq 5 \mu \mathrm{m}$ composed of crystal sizes of $0.1 \mu \mathrm{m}$ to $0.5 \mu \mathrm{m}$ ) with $400 \mathrm{mg}$ of IR quality $\mathrm{KBr}$ (about $20 \mu \mathrm{m}$ to $40 \mu \mathrm{m}$ particle sizes). Grinding the sample and $\mathrm{KBr}$ together was avoided to reduce additional moisture adsorption from the ground and smaller $\mathrm{KBr}$ particles. The HA-SRM and $\mathrm{KBr}$ were mixed in a steel capsule on a mechanical shaker and then pressed in a $13 \mathrm{~mm}$ diameter evacuated die under a total force of $53,380 \mathrm{~N}$ (12 000 pound-force) for $30 \mathrm{~s}$. One die face was machined nonparallel to the second die face, by about $1^{\circ}$. This nonparallel die face produced a wedge-shaped pellet, which reduced spectral interference fringes (especially important for second derivative spectra described below). Spectral slit widths were about 6 $\mathrm{cm}^{-1}$ for wavenumbers above $2000 \mathrm{~cm}^{-1}$ and $3 \mathrm{~cm}^{-1}$ to $5 \mathrm{~cm}^{-1}$ for wavenumbers below $2000 \mathrm{~cm}^{-1}$. The wavenumber standard uncertainty, calibrated against standard indene bands [14], was $1 \mathrm{~cm}^{-1}$ for sharp bands and several $\mathrm{cm}^{-1}$ for broad bands.

The ion charges for infrared and Raman bands of different ions are normally omitted in the text.

\subsubsection{IR Second Derivative Spectra}

Second derivative spectra of absorbance spectra for the $v_{3}$ and $v_{4} \mathrm{PO}_{4}$ bands were obtained in the ranges $1120 \mathrm{~cm}^{-1}$ to $1000 \mathrm{~cm}^{-1}$ and $670 \mathrm{~cm}^{-1}$ to $530 \mathrm{~cm}^{-1}$ with a Nicolet 550 Magna spectrometer purged with dry $\mathrm{CO}_{2}$-free air. The instrumental and data collection conditions were: deuterated triglycine sulfate detector at room temperature, $\mathrm{KBr}$ beam splitter, $1 \mathrm{~cm}^{-1}$ resolution, 1000 scans, $0.12 \mathrm{~cm}^{-1}$ data spacing, Happ-Genzel apodization, no smoothing of $v_{3} \mathrm{PO}_{4}$ absorbance spectrum, 25-point smoothing of $v_{4} \mathrm{PO}_{4}$ absorbance spectrum, and Nicolet Omnic software to obtain second derivative spectra of the absorbance spectra. High quality absorbance spectra without interference fringes and with low noise are required to obtain meaningful second derivative spectra. To help achieve this, the following were done: (1) to reduce interference fringes, wedge-shaped $\mathrm{KBr}$ pellets were prepared as described above $(400 \mathrm{mg}, 13 \mathrm{~mm}$ diameter with thickness increasing from $1.0 \mathrm{~mm}$ to about $1.2 \mathrm{~mm}$ across the pellet), (2) to eliminate the introduction of possible fringes in the background spectrum, the background for the sample was obtained from the empty pellet holder (no blank $\mathrm{KBr}$ pellet) in the spectrometer; and (3) to increase signal to noise, high sample concentrations and resultant high absorbance values of about 1.5 were used; the pellets contained $0.24 \mathrm{mg}$ and $1.0 \mathrm{mg}$ of HA-SRM for $v_{3} \mathrm{PO}_{4}$ and $v_{4} \mathrm{PO}_{4}$ spectra, respectively. $\mathrm{KBr}$ has no bands or impurity bands in the investigated regions. The second derivative wavenumber positions for the $v_{3}$ and $v_{4} \mathrm{PO}_{4}$ bands were determined with a standard uncertainty of $0.1 \mathrm{~cm}^{-1}$.

\subsection{Raman Spectroscopy}

Raman spectra were recorded with a Spex Model 1401 spectrometer in the $4000 \mathrm{~cm}^{-1}$ to $50 \mathrm{~cm}^{-1}$ region using the $488.0 \mathrm{~nm}$ wavelength excitation from an argon ion laser and a power of $320 \mathrm{~mW}$ measured at the sample. Spectra were obtained from about $4 \mathrm{mg}$ of sample powder that was tamped in a cylindrical well ( $2.5 \mathrm{~mm}$ diameter, $1 \mathrm{~mm}$ deep) in the center of an aluminum disk $1.5 \mathrm{~mm}$ thick and $13 \mathrm{~mm}$ in diameter followed by pressing under a sufficient force of about $71,170 \mathrm{~N}$ (16,000 pound-force) for $5 \mathrm{~s}$ to reduce disk thickness, constrict the sample well and compact the sample. The exciting radiation, upward and vertical, was focused on the compacted sample in the disk tilted about $30^{\circ}$ from the incoming radiation direction. Scattered radiation was collected at $90^{\circ}$ to the incoming 
beam direction and detected by a RCA C31034 photomultiplier cooled to $-25^{\circ} \mathrm{C}$.

The scattered radiation from the sample was passed through a $488.0 \mathrm{~nm}$ filter ${ }^{2}$ placed ahead of the spectrometer entrance slit to reduce the intensity of the $488.0 \mathrm{~nm}$ exciting line that was reflected from the opaque sample. This filter markedly reduced the intensity of the $488.0 \mathrm{~nm}$ line (about $10^{-4} \%$ of original); this enabled obtaining spectra to within about $50 \mathrm{~cm}^{-1}$ of the exciting line and also eliminated spurious "grating ghost" bands.

The spectral slit width was $3.5 \mathrm{~cm}^{-1}$. The wavenumber standard uncertainty was $\approx 0.5 \mathrm{~cm}^{-1}$, based on calibration using standard neon emission lines [15] from a neon lamp.

The baseline (BL) was obtained by reflecting the $488.0 \mathrm{~nm}$ line from a piece of rough surface platinum foil placed in the normal sample position. One spurious band was observed in the $\mathrm{BL}$ at $468 \mathrm{~cm}^{-1}$.

\subsection{X-Ray Diffraction}

The x-ray diffraction (XRD) patterns of the powdered HA-SRM samples (about $150 \mathrm{mg}$ in an aluminum holder) were obtained in the range of $3^{\circ} 2 \theta$ to $70^{\circ} 2 \theta$ with a Rigaku DMAX 2200 diffractometer operating at $40 \mathrm{kV}$ and $40 \mathrm{~mA}$, producing graphite-monochromatized $\mathrm{CuK} \alpha$ radiation with wavelength $\lambda=$ $0.15405945 \mathrm{~nm}$, and at a scan speed of $0.030^{\circ} 2 \theta / \mathrm{min}$. The relative intensities were determined as diffraction line heights relative to the most intense line normalized to the intensity of 100, with the Materials Data, Inc., JADE 6.1 XRD Patterns Processing software (MDI JADE 6.1).

For determination of diffraction line positions ( $2 \theta$-values), two samples were prepared by mixing HA-SRM with pre ground silicon (Silicon Powder $2 \theta / d$-Spacing Standard, NIST SRM 640b) that served as an internal standard to correct $2 \theta$-values of HA-SRM. The samples contained mass fractions of $88 \%$ HA-SRM and $12 \%$ silicon. Two separate scans with the speed of $0.012^{\circ} 2 \theta / \mathrm{min}$ were obtained for each sample. For each scan, the position of each HA-SRM and silicon diffraction line was determined with MDI JADE 6.1 as the average of four measurements using pseudo-Voigt and Pearson-VII profile functions (two measurements for each profile function).

The HA-SRM unitcell (lattice) parameters were calculated with the Least Squares Unit Cell Refinement

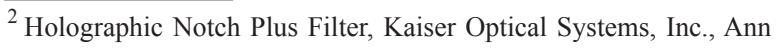
Arbor, MI 48103.
}

and Indexing for Personal Computer (LSUCRIPC) program $^{3}$; the input data were $2 \theta$-values and corresponding indices (hkl) of the eight diffraction lines in the range from $39^{\circ} 2 \theta$ to $54^{\circ} 2 \theta$, which have relative intensities above 10, and do not overlap with other HA-SRM and silicon diffraction lines. For each HA-SRM sample, the unit-cell parameters were calculated from the average $2 \theta$-values determined from the two separate scans. The final HA-SRM unit-cell parameters are the average of the data for the two samples.

Diffraction theory predicts that the diffraction lines of a XRD powder pattern will be very sharp for a crystalline material consisting of sufficiently large and strain-free crystallites [16]; therefore, the XRD line broadening (peak width) inversely correlates with crystal size and lattice perfection. The term "crystallinity" is commonly used to represent the crystallite size and lattice perfection. For determination of diffraction line angular width at its half-height, the lines having $h \mathrm{kl}$ indices (200), (002), (102), (210), (310) and (004) were recorded earlier with a vertically mounted Rigaku Denki diffractometer system operating at $40 \mathrm{kV}$ and $25 \mathrm{~mA}$, producing graphitemonochromatized $\mathrm{CuK} \alpha$ radiation with wavelength $\lambda=0.15405945 \mathrm{~nm}$ (time constant 10 , scale 500 counts $/ \mathrm{s}$, scan speed $0.03125^{\circ}$ $2 \theta / \mathrm{min})$. The diffraction line angular width, $B$, at its half-height above background was measured with an optical magnifier and expressed in ${ }^{\circ} 2 \theta$. The angular width $(B)$ was corrected for instrumental line broadening $(b)$ caused by instrument imperfections [16]. The corrected value of the angular width $(\beta)$ expressed in $\circ 2 \theta$, was calculated from Warren's equation [16]

$$
\beta=\left(\beta^{2}-b^{2}\right)^{1 / 2}
$$

A stoichiometric, highly crystalline monoclinic hydroxyapatite (hc-HA) prepared by solid-state thermal reaction [17] was used as a reference substance in determination of the value of $b$ (the angular width at the halfheight of hc-HA diffraction lines). The $b$-values for hc-HA diffraction lines were determined for the same six lines as for HA-SRM.

The reciprocal of the $\beta$ value $(1 / \beta)$ correlates to the crystallite size/perfection [16].

\footnotetext{
${ }^{3}$ Least Squares Unit Cell Refinement, NDSU version Fargo 90.10.13.em after Appleman and Evans (1973), implementation by Roy G. Garvey, Department of Chemistry, North Dakota State University, Fargo, ND 58105-5516.
} 


\subsection{Statistical Analysis}

Uncertainties were assessed by the CIPM (International Committee for Weights and Measures) approach [18]. The uncertainty of a measurement result commonly consists of several components. An estimated standard deviation called a standard uncertainty, $u_{\mathrm{i}}$, represents a component of uncertainty. A combined standard uncertainty, $u_{\mathrm{c}}$, was computed by the method of propagation of uncertainties $[18,19]$ and represents at the level of one standard deviation the combined effects of all standard uncertainties, $u_{\mathrm{i}}$ 's. According to the CIPM recommendation [18] the uncertainty of a measurement result is expressed with expanded uncertainty, $U$. Results in this paper, except as noted, are expressed as mean value $\pm U$, where $U=2 u_{\mathrm{c}}$.

\section{Results and Discussion}

\subsection{Chemical Composition}

\subsubsection{Calcium}

The mass fraction of calcium in HA-SRM varied from $38.78 \%$ to $39.49 \%$ with a mean value of $39.15 \% \pm 0.10 \%$ (Table 1 ).

\subsubsection{Phosphorus}

The mass fraction of the total phosphorus content in HA-SRM varied from $18.111 \%$ to $18.235 \%$ with a mean value of $18.181 \% \pm 0.037 \%$.

\subsubsection{Ca/P Molar Ratio}

From the mean values of $\mathrm{Ca}$ and $\mathrm{P}$ contents the calculated $\mathrm{Ca} / \mathrm{P}$ molar ratio was $1.664 \pm 0.005$. This value is in agreement with the ratio of $1.6649 \pm 0.0005$ independently determined for this HA-SRM by thermalproduct analysis $[6,8]$. The $\mathrm{Ca} / \mathrm{P}$ ratio of 1.664 for this HA-SRM is about $0.2 \%$ below the stoichiometric value of 1.6667 .

\subsubsection{Hydrogenphosphate and Phosphate}

The mass fraction of phosphorus present in the form of hydrogenphosphate ions $\left(\mathrm{HPO}_{4}{ }^{2-}\right)$ was $0.191 \% \pm 0.010 \%$ and accordingly, the mass fraction of $\mathrm{HPO}_{4}{ }^{2-}$ was $0.592 \% \pm 0.030 \%$ (Table 1 ). The mass fraction of phosphorus present in the form of phosphate ions $\left(\mathrm{PO}_{4}{ }^{3-}\right)$ is the difference between mass fractions of the total phosphorus content $(18.181 \% \pm 0.037 \%)$ and of phosphorus present as $\mathrm{HPO}_{4}^{2-}(0.191 \% \pm 0.010 \%)$, giving the mass fraction of phosphorus present as $\mathrm{PO}_{4}{ }^{3}$ of $17.99 \% \pm 0.05 \%$. From this value the calculated mass fraction of $\mathrm{PO}_{4}{ }^{3-}$ was $55.16 \% \pm 0.15 \%$ (Table 1 ).

Table 1. Chemical composition of calcium hydroxyapatite standard reference material (HA-SRM) along with the calculated number and total relative charge of constituent ions per HA-SRM unit cell ${ }^{\mathrm{a}}$

\begin{tabular}{lllll}
\hline \hline Constituent & Mass fraction (\%) & $n^{\mathrm{b}}$ & $\begin{array}{l}\text { Number of constituent } \\
\text { ions/HA-SRM unit cell }\end{array}$ & $\begin{array}{c}\text { Total relative charge of } \\
\text { constituent ions/HA-SRM } \\
\text { unit cell }^{\mathrm{d}}\end{array}$ \\
\hline $\mathrm{Ca}^{2+}$ & & 20 & $9.985 \pm 0.026$ & $+19.970 \pm 0.051$ \\
$\mathrm{PO}_{4}{ }^{3-}$ & $39.15 \pm 0.10$ & 20 & $5.937 \pm 0.016$ & $-17.811 \pm 0.048$ \\
$\mathrm{HPO}_{4}{ }^{2-}$ & $55.16 \pm 0.15$ & 4 & $0.063 \pm 0.003$ & $-0.126 \pm 0.006$ \\
$\mathrm{H}_{2} \mathrm{O}$ & $0.592 \pm 0.030$ & 5 & $0.902 \pm 0.028$ & $-0.0109 \pm 0.0007$ \\
$\mathrm{CO}_{3}{ }^{2-}$ & $1.59 \pm 0.05$ & 12 & $0.00545 \pm 0.00034$ & -0.0109 \\
$\mathrm{SiO}_{3}{ }^{2-}$ & $0.032 \pm 0.002$ & 1 & 0.00546 & +0.0144 \\
$\mathrm{Trace} \mathrm{elements}^{\mathrm{f}}$ & $0.0406^{\mathrm{f}}$ & 1 & $0.00595^{\mathrm{f}}$ & $-2.026^{\mathrm{g}} \pm 0.070$ \\
$\mathrm{OH}$ & $0.0181^{\mathrm{f}}$ & & $2.026^{\mathrm{h}} \pm 0.070$ & 0 \\
\hline \multicolumn{1}{c}{ Sum } & $3.37^{\mathrm{h}} \pm 0.12$ & & & 0 \\
\hline
\end{tabular}

\footnotetext{
${ }^{\text {a }}$ All results expressed as mean value $\pm U$, where $U$ is expanded uncertainty.

${ }^{\mathrm{b}}$ Number of replicate measurements.

${ }^{c}$ Number of constituent ions normalized to six phosphate groups $\left(5.937 \mathrm{PO}_{4}+0.063 \mathrm{HPO}_{4}\right)$.

${ }^{\mathrm{d}}$ Calculated from relative electrical charge of the constituent ion time number of the constituent ions.

${ }^{\mathrm{e}}$ Calculated from silicon content in Table 2.

${ }^{\mathrm{f}}$ From Table 2.

${ }^{\mathrm{g}}$ Calculated to balance total charge to 0 .

${ }^{\mathrm{h}}$ Derived from calculated relative charge of $-2.026^{\mathrm{g}}$.
} 
The contents of $\mathrm{PO}_{4}{ }^{3-}$ and $\mathrm{HPO}_{4}{ }^{2-}$ expressed as molar fractions of the total phosphate content were $98.95 \%$ and $1.05 \%$, respectively.

\subsubsection{Water}

The total mass loss (expressed as the mass fraction) of samples heated continuously from $30{ }^{\circ} \mathrm{C}$ to $900{ }^{\circ} \mathrm{C}$ in a nitrogen atmosphere was $1.70 \% \pm 0.05 \%$. This mass loss is primarily attributed to water loss based on water band intensity changes in the IR spectrum of HA-SRM heated at $105^{\circ} \mathrm{C}$ and $850^{\circ} \mathrm{C}$. The HA-SRM water content is the difference between the mass fractions of the total mass loss $(1.70 \% \pm 0.05 \%)$ and the water loss derived from hydrogenphosphate pyrolysis into pyrophosphate and thermal reaction of calcium pyrophosphate and HA forming $\beta$-tricalcium phosphate; the calculated mass fraction of water derived from these thermal/chemical reactions was $0.111 \% \pm 0.006 \%$. Therefore, the mass fraction of water in HA-SRM was $1.59 \% \pm 0.05 \%$ or $0.902 \mathrm{H}_{2} \mathrm{O}$ molecule per HA-SRM unit cell (Table 1).

The TG-curve for HA-SRM (Fig. 1) is shown in the temperature range from $30^{\circ} \mathrm{C}$ to $900{ }^{\circ} \mathrm{C}$; on the left ordinate is mass fraction and on the right ordinate is the corresponding calculated number of water layers progressively removed from the HA-SRM surface. The number of water layers on the HA-SRM surface was calculated from the HA-SRM surface area of $18.3 \mathrm{~m}^{2} / \mathrm{g}$ (Section 3.2) and a cross-sectional area of $0.115 \mathrm{~nm}^{2}$ for an adsorbed water molecule [20] on the HA surface; one monolayer of water corresponds to the mass fraction of $0.47 \%$. Rootare and Craig [20] have carried out detailed studies of vapor phase adsorption of water on HA. They found that the water monolayer that is in

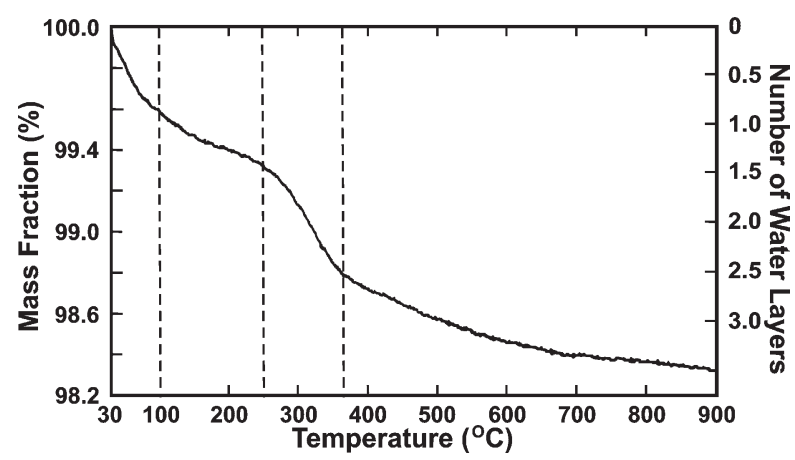

Fig. 1. TG-curve for HA-SRM in the temperature range from $30^{\circ} \mathrm{C}$ to $900{ }^{\circ} \mathrm{C}$ in a nitrogen atmosphere. The left ordinate denotes the mass fraction and the right ordinate gives the corresponding calculated number of water layers progressively removed from the HA-SRM surface. contact with the HA surface (chemisorbed layer) was more strongly bound than the additional water layers (all physisorbed layers) that involved water/water contacts only. To completely remove the chemisorbed monolayer, heating at $300{ }^{\circ} \mathrm{C}$ in vacuum was required whereas the physisorbed layers could be removed at $20^{\circ} \mathrm{C}$ in vacuum.

The TG-curve (Fig. 1) showed an initial mass loss (expressed as mass fraction) of $\approx 0.4 \%$ in the temperature range from $30{ }^{\circ} \mathrm{C}$ to $100{ }^{\circ} \mathrm{C}$ and a mass loss of $\approx 0.3 \%$ in the range from $100{ }^{\circ} \mathrm{C}$ to $250{ }^{\circ} \mathrm{C}$. These two losses (mass fractions), giving a sum of $\approx 0.7 \%$, correspond to $\approx 1.5$ layers mainly of physisorbed water although some chemisorbed water is also expected to be lost between $100{ }^{\circ} \mathrm{C}$ and $250^{\circ} \mathrm{C}$ [20]. Between $250{ }^{\circ} \mathrm{C}$ and $360{ }^{\circ} \mathrm{C}$, a loss of $\approx 0.55 \%$ was observed which corresponds to $\approx 1$ layer of chemisorbed water. This temperature range, $250{ }^{\circ} \mathrm{C}$ to $360^{\circ} \mathrm{C}$, and mass loss equivalent to $\approx 1$ water layer are consistent with data of Rootare and Craig [20] for the chemisorbed water layer. The mass fraction lost in the temperature range from $360{ }^{\circ} \mathrm{C}$ to $850{ }^{\circ} \mathrm{C}$ was $\approx 0.45 \%$. Of this $\approx 0.45 \%, \approx 0.11 \%$ corresponds to water loss from $\mathrm{HPO}_{4}^{2-} / \mathrm{P}_{2} \mathrm{O}_{7}{ }^{4} / \mathrm{HA} / \beta$-TCP reactions, $\approx 0.02 \%$ corresponds to loss from $\mathrm{CO}_{3}{ }^{2-}$ decomposition on heating to $850{ }^{\circ} \mathrm{C}$ and the remainder of $\approx 0.32 \%$ corresponds to $\approx 0.7$ layer of water that is more strongly held by the crystals than the chemisorbed layer.

From these TG-data it appeared that the total number of water layers at the surface of the HA-SRM crystals was $\approx 2.5 ; \approx 1.5$ layers correspond to physisorbed water and $\approx 1$ layer to chemisorbed water. The location of the more strongly-held water, equivalent to $\approx 0.7$ layer or about one water molecule per 5.6 HA-SRM unit cells is uncertain. It may be "structural" water or water trapped within crystals.

The mass fraction of water in HA-SRM determined from mass loss of powdered HA-SRM samples heated in air at $850{ }^{\circ} \mathrm{C}$ for $16 \mathrm{~h}$ to $20 \mathrm{~h}$, then cooled in a desiccator and weighed in the laboratory atmosphere (50\% relative humidity) at ambient temperature was $1.430 \% \pm 0.034 \%$, whereas the mass fraction of water in HA-SRM determined in samples pressed into pellets and heated in a steam atmosphere at $1000^{\circ} \mathrm{C}$ for $10 \mathrm{~h}$ and then cooled and weighed as above was $1.564 \% \pm 0.028 \%$. In both cases the HA-SRM water content was lower than in the samples heated and weighed in the nitrogen atmosphere because of fast readsorption of surface water during cooling and weighing in the air atmosphere at ambient temperature. 


\subsubsection{Carbonate}

Carbonate ions are a common impurity in HA. The mass fraction of carbonate found in HA-SRM was in the range from $0.029 \%$ to $0.033 \%$ with the mean value of $0.032 \% \pm 0.002 \%$ (Table 1 ). This carbonate content corresponds to $0.00545 \mathrm{CO}_{3}^{2-}$ ion per HA-SRM unit cell (Table 1) or to one $\mathrm{CO}_{3}^{2-}$ ion per 183 HA-SRM unit cells.

\subsubsection{Silicate}

The mass fraction of silicon of $0.015 \%$ (Table 2) expressed as mass fraction of silicate ions, $\mathrm{SiO}_{3}{ }^{2-}$, was $0.0406 \%$ (Table 1). This content corresponds to $0.00546 \mathrm{SiO}_{3}^{2-}$ ion per HA-SRM unit cell or to one $\mathrm{SiO}_{3}{ }^{2-}$ ion per 183 HA-SRM unit cells. The source of the silicon impurity was most plausibly the boro-silicate glass apparatus used in preparation of HA-SRM.

\subsubsection{Trace Constituents}

Trace constituents with mass fractions above $0.0005 \%(>5 \mathrm{ppm})$ in HA-SRM are listed in Table 2 and summarized in Table 1. Approximately 0.001 atom each of Al, B, Mg, Na and Sr occurs per HA-SRM unit cell (Table 2), which corresponds to approximately one of each atom per 1000 unit cells. The sum of trace constituent atoms of 0.00595 per HA-SRM unit cell (Table 1) corresponds to one trace constituent atom per 168 HA-SRM unit cells.

Table 2. Contents of trace constituents ${ }^{\mathrm{a}}$ and silicon in HA-SRM

\begin{tabular}{lcc}
\hline \hline $\begin{array}{c}\text { Trace } \\
\text { constituent }\end{array}$ & $\begin{array}{c}\text { Mass } \\
\text { fraction } \\
(\%)\end{array}$ & $\begin{array}{c}\text { Number of } \\
\text { ions/HA-SRM } \\
\text { unit cell }\end{array}$ \\
\hline $\mathrm{Al}^{3+}$ & 0.0029 & 0.00110 \\
$\mathrm{Ba}^{2+}$ & 0.0024 & 0.00018 \\
$\mathrm{~B}^{3+}$ & 0.0015 & 0.00142 \\
$\mathrm{Mg}^{2+}$ & 0.0029 & 0.00122 \\
$\mathrm{Na}^{2+}$ & 0.0031 & 0.00138 \\
$\mathrm{Sr}^{2+}$ & 0.0044 & 0.00051 \\
$\mathrm{Zn}^{2+}$ & 0.0009 & 0.00014 \\
\hline $\mathrm{Sum}$ & 0.0181 & 0.00595 \\
\hline $\mathrm{Si}$ & 0.0150 & 0.00546 \\
\hline
\end{tabular}

${ }^{\mathrm{a}}$ Trace constituents having mass fraction $>0.0005 \%$ are included.

${ }^{\mathrm{b}}$ Calculated number of ions per unit-cell.

\subsubsection{Hydroxide}

In Table 1 are listed the contents of analyzed HA-SRM constituents: calcium, phosphate, hydrogenphosphate, water, carbonate, silicate and sum of trace constituents. From these contents the number of constituents per HA-SRM unit cell was calculated by normalizing the total number of phosphate groups $\left(\mathrm{PO}_{4}{ }^{3-}\right.$ and $\mathrm{HPO}_{4}{ }^{2-}$ ) to six, $5.937 \mathrm{PO}_{4}{ }^{3-}$ and $0.063 \mathrm{HPO}_{4}{ }^{2-}$. The relative charge attributed to the total number of hydroxide ions $\left(\mathrm{OH}^{-}\right)$per unit cell was calculated from the difference between positive and negative relative charges of all unit-cell constituents; a mean value of -2.026 for $\mathrm{OH}^{-}$ions balanced the total charge to zero. This calculated number of $2.026 \pm 0.070$ of $\mathrm{OH}^{-}$ions per HA-SRM unit cell corresponds to the mass fraction of $3.37 \% \pm 0.12 \%$ of $\mathrm{OH}^{-}$in HA-SRM (Table 1 ).

\subsubsection{Sum of Mass Fractions}

The total sum of mass fractions of all constituents was $99.95 \% \pm 0.22 \%$ (Table 1 ); this shows high accuracy of the chemical analyses.

\subsection{Crystal Morphology and Specific Surface Area}

Transmission and scanning electron micrographs of the HA-SRM crystals are shown in Fig. 2. Generally, the crystals appear to have a cylindrical shape with heights of $\approx 0.1 \mu \mathrm{m}$ to $0.3 \mu \mathrm{m}$ and diameters of $\approx 0.05 \mu \mathrm{m}$ to $0.15 \mu \mathrm{m}$. The specific surface area determined by BET was $17.7 \mathrm{~m}^{2} / \mathrm{g}$ to $19.1 \mathrm{~m}^{2} / \mathrm{g}$ with an average value of $18.3 \mathrm{~m}^{2} / \mathrm{g} \pm 0.3 \mathrm{~m}^{2} / \mathrm{g}$. This specific surface area for the HA-SRM crystals compares well with the value of $16.6 \mathrm{~m}^{2} / \mathrm{g}$ calculated by assuming an average cylindrical particle with height of $0.2 \mu \mathrm{m}$ and diameter of $0.1 \mu \mathrm{m}$.

The HA sample of McDowell et al. prepared by precipitation from solutions had a specific surface area of $16.7 \mathrm{~m}^{2} / \mathrm{g}$ determined by BET [9]. This value of $16.7 \mathrm{~m}^{2} / \mathrm{g}$ is in agreement with the above value of $18.3 \mathrm{~m}^{2} / \mathrm{g}$ for HA-SRM. These data indicate the reproducibility of crystal sizes and surface area of HAs prepared by the same method.

\subsection{Infrared Spectra}

\subsubsection{IR Transmittance Spectra}

IR transmittance spectra of HA-SRM at two different concentrations $(0.8 \mathrm{mg}$ and $4.0 \mathrm{mg}$ HA-SRM per 


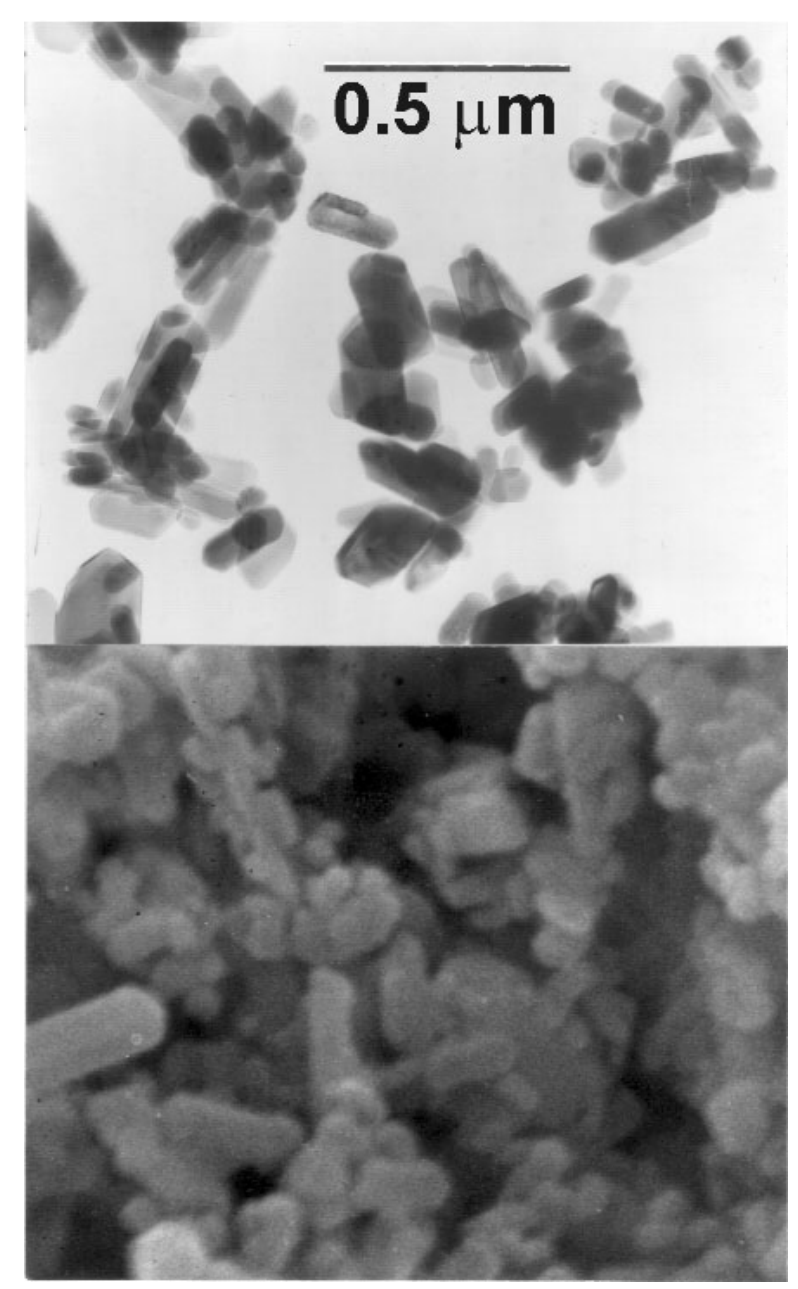

Fig. 2. Transmission electron micrograph (top) and scanning electron micrograph (bottom) of the HA-SRM crystals. Both micrographs have the same magnification and the bar length in the top micrograph is $0.5 \mu \mathrm{m}$.

$400 \mathrm{mg} \mathrm{KBr}$ ) are shown in the $4000 \mathrm{~cm}^{-1}$ to $300 \mathrm{~cm}^{-1}$ range in Fig. 3. The spectra show the bands of HA along with additional bands that are ascribed to impurity ions $\left(\mathrm{CO}_{3}{ }^{2-}, \mathrm{HPO}_{4}{ }^{2-}\right.$, and silicate ions), and associated $\mathrm{H}_{2} \mathrm{O}$.

Bands of HA [21]: (a) The bands at $3572 \mathrm{~cm}^{-1}$, $631 \mathrm{~cm}^{-1}$, and $342 \mathrm{~cm}^{-1}$ arise from stretching, librational, and translational modes, respectively, of $\mathrm{OH}^{-}$ ions. (b) The $1090 \mathrm{~cm}^{-1}$ and about $1040 \mathrm{~cm}^{-1}$ bands arise from $v_{3} \mathrm{PO}_{4}$, the $962 \mathrm{~cm}^{-1}$ band arises from $v_{1} \mathrm{PO}_{4}$, the $601 \mathrm{~cm}^{-1}$ and $574 \mathrm{~cm}^{-1}$ bands arise from $v_{4} \mathrm{PO}_{4}$, and the $472 \mathrm{~cm}^{-1}$ band arises from $v_{2} \mathrm{PO}_{4}$. (c) The group of weak intensity bands in the $2200 \mathrm{~cm}^{-1}$ to $1950 \mathrm{~cm}^{-1}$ region derives from overtones and combinations of the $v_{3}$ and $v_{1} \mathrm{PO}_{4}$ modes. The sharpness of bands, especial- ly sharpness of the $631 \mathrm{~cm}^{-1}, 601 \mathrm{~cm}^{-1}$, and $574 \mathrm{~cm}^{-1}$ bands, indicate a well-crystallized HA.

Bands of $\mathrm{CO}_{3}{ }^{2-}$ impurity ions: The weak intensity bands at about $1410 \mathrm{~cm}^{-1}$ and $1450 \mathrm{~cm}^{-1}$ in the spectrum of HA-SRM at high concentration $(4.0 \mathrm{mg}$ of HA-SRM per $400 \mathrm{mg} \mathrm{KBr}$ ) are attributed to components of the $v_{3}$ mode of a trace amount of $\mathrm{CO}_{3}{ }^{2-}$. The mass fraction of $\mathrm{CO}_{3}{ }^{2-}$ in HA-SRM determined by chemical analysis, Sec. 3.1.6, was $0.032 \%$. The areas and intensities of these $\mathrm{CO}_{3}$ bands correspond to mass fraction of about $0.03 \% \mathrm{CO}_{3}{ }^{2-}$ by comparison to $\mathrm{CO}_{3}$ bands of other HA samples [6] containing chemically analyzed $\mathrm{CO}_{3}{ }^{2-}$ mass fractions of about $0.3 \%$; this band intensity agreement for this low $\mathrm{CO}_{3}{ }^{2-}$ content helps identify these weak intensity bands as $\mathrm{CO}_{3}$ bands. Bands of other $\mathrm{CO}_{3}$ modes, $v_{4}$ and $v_{1}$, were not detected because of their weak intensities and the $v_{2} \mathrm{CO}_{3}$ band at about $872 \mathrm{~cm}^{-1}$, with intensity about one fifth that of $v_{3} \mathrm{CO}_{3}$, is obscured by the $\mathrm{HPO}_{4}$ band at $875 \mathrm{~cm}^{-1}$. The $\mathrm{CO}_{3}$ bands at $1410 \mathrm{~cm}^{-1}$ and $1450 \mathrm{~cm}^{-1}$ derive from $\mathrm{CO}_{3}{ }^{2-}$ (designated the "B-type" carbonate) that replace $\mathrm{PO}_{4}{ }^{3-}$ ions in the $\mathrm{HA}$ lattice [22] (and references therein). Bands at $1455 \mathrm{~cm}^{-1}$ and about $1540 \mathrm{~cm}^{-1}$, which derive from $\mathrm{CO}_{3}{ }^{2-}$ (designated the "A-type" carbonate) that replace $\mathrm{OH}^{-}$ions in the $\mathrm{HA}$ lattice [23], were not detected. The mass fraction of $0.032 \%$ chemically determined $\mathrm{CO}_{3}{ }^{2-}$, corresponds to one $\mathrm{CO}_{3}{ }^{2-}$ ion per 1101 total phosphate ions $\left(\mathrm{PO}_{4}{ }^{3-}\right.$ and $\mathrm{HPO}_{4}^{2-}$ ).

Bands of $\mathrm{HPO}_{4}{ }^{2-}$ impurity ions: The band at $875 \mathrm{~cm}^{-1}$ is attributed to arise from $\mathrm{HPO}_{4}^{2-}$ ions for several reasons [24,25]. Chemical analysis shows that HA-SRM contains $1.05 \mathrm{HPO}_{4}{ }^{2-}$ ions per $98.95 \mathrm{PO}_{4}{ }^{3-}$ ions (Sec. 3.1 .4 , Table 1) or molar fraction of $1.05 \% \mathrm{HPO}_{4}{ }^{2-}$ with respect to the total $\mathrm{P}$ content. The isolated $\mathrm{HPO}_{4}{ }^{2-}$ ion has 9 predicted infrared active internal modes for its highest symmetry point group, $\mathrm{C}_{3 \mathrm{v}}$, and 12 predicted infrared active modes for its lowest symmetry point group, $\mathrm{C}_{1}$. At this very low molar fraction of $1.05 \%$ $\mathrm{HPO}_{4}{ }^{2-}$, of the 9 to 12 possible bands, only the $875 \mathrm{~cm}^{-1}$ band is clearly detectable; the other $\mathrm{HPO}_{4}$ bands are obscured by the $\mathrm{PO}_{4}$ bands of $\mathrm{HA}$ and, in addition, the (-O-H) bands of the $\mathrm{HOPO}_{3}{ }^{2-}$ ions are broad and weak in intensity. The normalized intensity and area of the $875 \mathrm{~cm}^{-1}$ band correlates with $\mathrm{HPO}_{4}{ }^{2-}$ content determined by chemical analysis. A HA sample containing a $\mathrm{HPO}_{4}^{2-}$ molar fraction of $2.34 \%$ by chemical analysis $[3,6]$ had a $875 \mathrm{~cm}^{-1}$ normalized band area 2.1 times that of the HA-SRM that contained $\mathrm{HPO}_{4}{ }^{2-}$ molar fraction of $1.05 \%$ determined by chemical analysis. In addition, this $875 \mathrm{~cm}^{-1} \mathrm{HPO}_{4}$ band was, as expected, missing in spectra of HA-SRM that had been heated at 


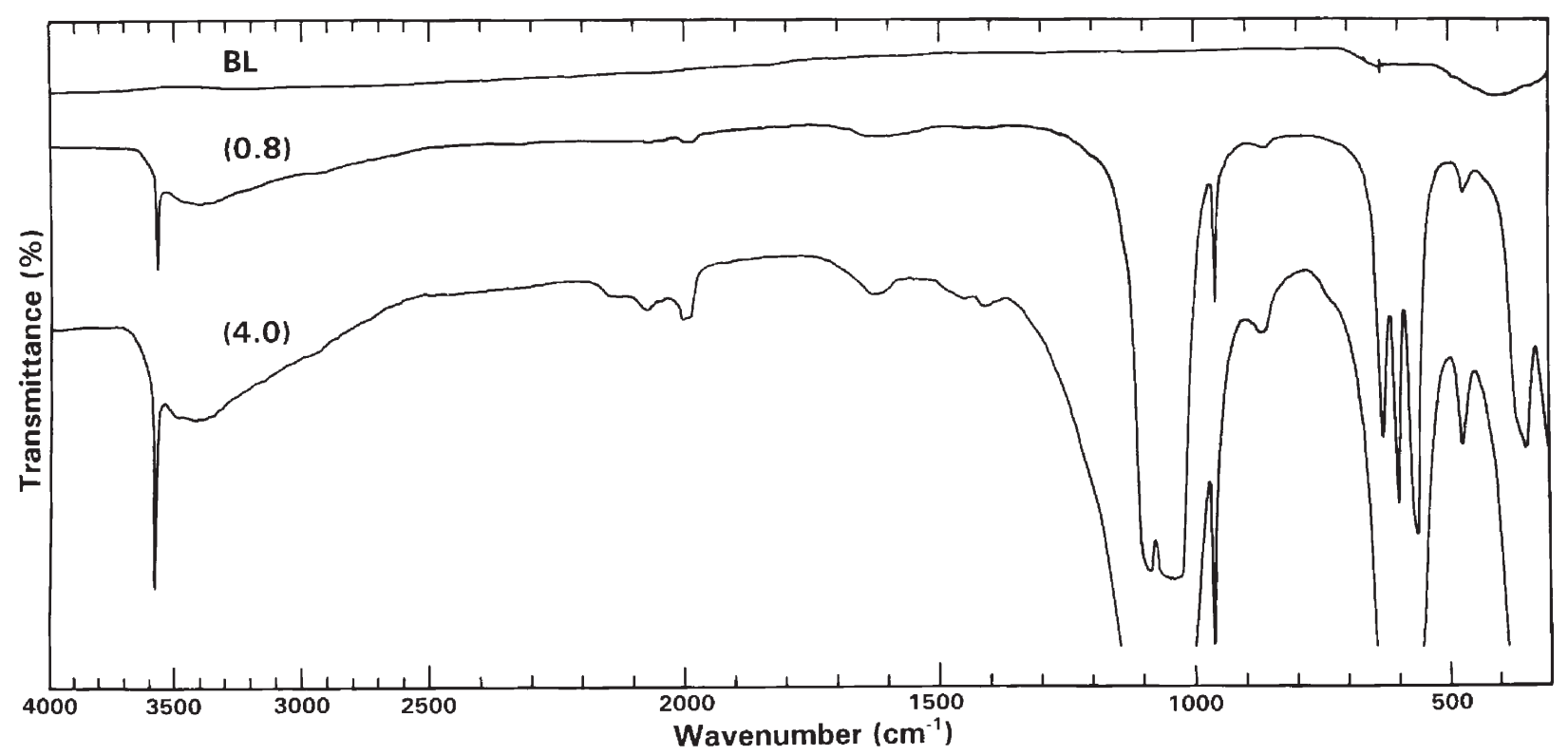

Fig. 3. Infrared percent transmittance spectra of HA-SRM from concentrations of $0.8 \mathrm{mg}$ and $4.0 \mathrm{mg}$ of HA-SRM/400 $\mathrm{mg}$ of KBr in the $4000 \mathrm{~cm}^{-1}$ to $300 \mathrm{~cm}^{-1}$ region. BL denotes the $\mathrm{KBr}$ pellet baseline.

$550{ }^{\circ} \mathrm{C}$ because of condensation of $\mathrm{HPO}_{4}{ }^{2-}$ ions to form $\mathrm{P}_{2} \mathrm{O}_{7}^{4}$ ions and $\mathrm{H}_{2} \mathrm{O}$.

Bands of silicate impurity ions: The mass fraction of $\mathrm{Si}$ in HA-SRM determined by chemical analyses was $0.015 \%$ (Sec. 3.1.7); the mass fraction calculated as the $\mathrm{SiO}_{3}^{2-}$ was $0.0406 \%$ (Table 1). Previous work [6] on other HAs prepared by precipitation in glass apparatus from solution at $100^{\circ} \mathrm{C}$ and high $\mathrm{pH}$ produced HAs that contained Si mass fraction of about $0.1 \%$ to $0.3 \%$ determined by chemical analyses. IR spectra of these HAs had weak bands, not deriving from $\mathrm{HA}$, at $890 \mathrm{~cm}^{-1}, \approx 830 \mathrm{~cm}^{-1}, \approx 750 \mathrm{~cm}^{-1}$ and $\approx 500 \mathrm{~cm}^{-1}$ and a Raman band at $890 \mathrm{~cm}^{-1}$ whose intensities correlated with silicon content. Consequently, these bands were attributed to silicate ions, and their most probable source was the glass apparatus. The type of silicate ion $\mathrm{SiO}_{3}^{2-}$ (chain or ring structures), $\mathrm{Si}_{2} \mathrm{O}_{7}^{6-}$, or $\mathrm{SiO}_{4}^{4-}$ in these HAs was not identified with certainty by IR or Raman methods primarily because of the low silicate contents and resultant weak band intensities along with interference from the strong HA bands. Nevertheless, the combined IR and Raman data and additional thermal data suggested that $\left(\mathrm{SiO}_{3}{ }^{2-}\right)_{3}=\mathrm{Si}_{3} \mathrm{O}_{9}{ }^{6-}$ ring and $\mathrm{Si}_{2} \mathrm{O}_{7}{ }^{6-}$ ions may be present and $\mathrm{SiO}_{4}{ }^{4-}$ and acidic silicates less probable. The high concentration spectrum of HA-SRM in Fig. 3 has very weak bands at $890 \mathrm{~cm}^{-1}$ and $\approx 750 \mathrm{~cm}^{-1}$; these two bands are better discerned in the high concentration spectrum of the heated HA-SRM that will be shown in the paper on monoclinic HA [8].
These $890 \mathrm{~cm}^{-1}$ and $750 \mathrm{~cm}^{-1}$ bands are attributed to silicate ions and are assumed to be $\mathrm{SiO}_{3}^{2-}$ ions.

Bands of $\mathrm{H}_{2} \mathrm{O}$ molecules: The broad band from about $3700 \mathrm{~cm}^{-1}$ to $2500 \mathrm{~cm}^{-1}$ derives from the $v_{3}$ and $v_{1}$ stretching modes of hydrogen-bonded $\mathrm{H}_{2} \mathrm{O}$ molecules, and the band at $1630 \mathrm{~cm}^{-1}$ derives from the $v_{2}$ bending mode of the $\mathrm{H}_{2} \mathrm{O}$ molecules. The thermogravimetric data in Table 1 show a mean mass loss (expressed as mass fraction) of $1.59 \%$ on heating HA-SRM that is primarily attributed to loss of adsorbed water. In the IR spectra of HA-SRM after heating at $850^{\circ} \mathrm{C}$ [8], the above water bands are, as expected, missing; this indirectly identifies $\mathrm{H}_{2} \mathrm{O}$ as the principal component lost on heating.

\subsubsection{IR Second Derivative Spectra}

IR second derivative spectra of the $v_{3}$ and $v_{4} \mathrm{PO}_{4}$ bands are shown in Fig. 4 and Fig. 5, respectively, and the second derivative band positions are given in Table 3. Second derivative spectra of the $v_{1}$ and $v_{2} \mathrm{PO}_{4}$ bands are not shown. Only one $v_{1} \mathrm{PO}_{4}$ band was detected at $962.9 \mathrm{~cm}^{-1}$ in second derivative spectra and the instrument detector response, progressively lower in the $500 \mathrm{~cm}^{-1}$ to $400 \mathrm{~cm}^{-1}$ region along with the weak $v_{2} \mathrm{PO}_{4}$ band intensity, precluded obtaining well-resolved second derivative spectra of the $v_{2} \mathrm{PO}_{4}$ band although the bands occur at about $474 \mathrm{~cm}^{-1}$ and $462 \mathrm{~cm}^{-1}$. Under $1 \mathrm{~cm}^{-1}$ resolution, eleven $v_{3} \mathrm{PO}_{4}$ bands were resolved 


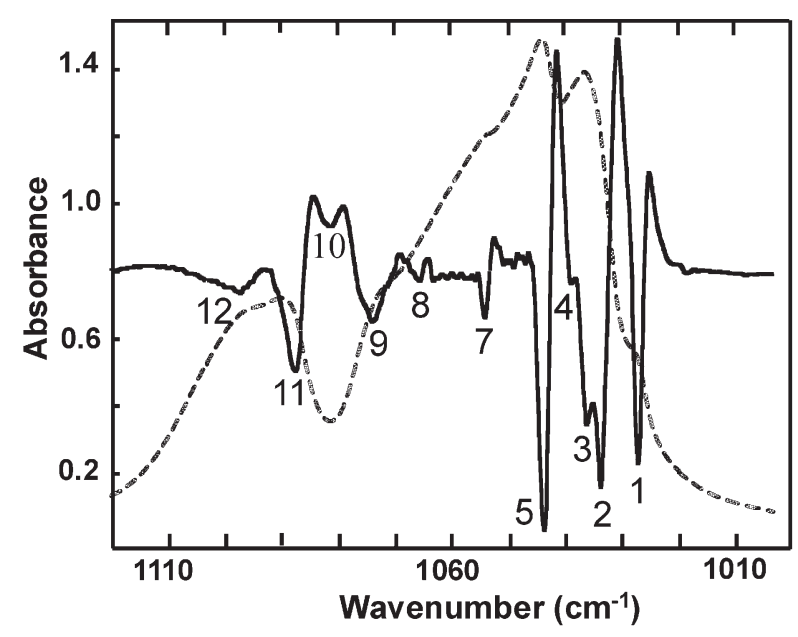

Fig. 4. Infrared absorbance spectrum of the $v_{3} \mathrm{PO}_{4}$ mode of HA-SRM (dashed line) and second derivative of the absorbance spectrum (solid line). The second derivative spectrum ordinate scale, not shown, is arbitrary. The second derivative spectrum was adjusted to full ordinate range and the minima denoted by numbers identify band positions in the absorbance spectrum.

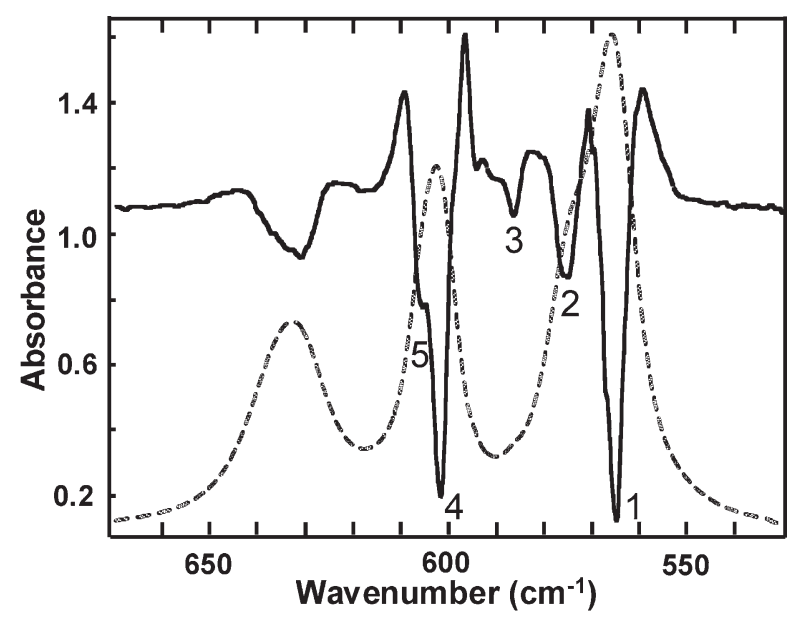

Fig. 5. Infrared absorbance spectrum of the $v_{4} \mathrm{PO}_{4}$ mode of HA-SRM (dashed line) and second derivative of the absorbance spectrum (solid line). The absorbance band at $633 \mathrm{~cm}^{-1}$ and second derivative band at $633 \mathrm{~cm}^{-1}$ derive from the $\mathrm{OH}^{-}$librational mode. The description of the second derivative spectrum is the same as that given in Fig. 4.

(Fig. 4). Two of these bands, numbered 3 and 4 in Fig. 4 and in Table 3, are attributed to arise from the mass fraction of about $25 \%$ of monoclinic HA; these bands will be discussed in the paper on monoclinic HA [8]. Thus, nine bands were detected for the $v_{3} \mathrm{PO}_{4}$ mode of this hexagonal HA-SRM. In Fig. 5, five second derivative $v_{4} \mathrm{PO}_{4}$ bands were detected; the absorbance band and second derivative band at $633 \mathrm{~cm}^{-1}$ derive from the $\mathrm{OH}^{-}$librational mode.
Table 3. IR wavenumber positions of $v_{3}$ and $v_{4} \mathrm{PO}_{4}$ bands of HA-SRM obtained from second derivative spectra

\begin{tabular}{ccc}
\hline \hline & \multicolumn{2}{c}{$\mathrm{PO}_{4}$ bands $\left(\mathrm{cm}^{-1}\right)$} \\
Band number $^{\mathrm{a}}$ & $v_{3}$ & $v_{4}$ \\
\hline 1 & 1027.0 & 565.1 \\
2 & 1033.7 & 575.3 \\
3 & $1036.0^{\mathrm{b}}$ & 586.4 \\
4 & $1038.7^{\mathrm{b}}$ & 601.8 \\
5 & 1043.6 & 605.4 \\
6 & & \\
7 & 1054.0 & \\
8 & 1065.4 & \\
9 & 1073.9 & \\
10 & 1081.3 & \\
11 & 1087.7 & \\
12 & 1097.5 & \\
\hline
\end{tabular}

${ }^{a}$ Refer to Figs. 4 and 5 .

${ }^{\mathrm{b}}$ These two bands are attributed to arise from monoclinic HA (mass fraction $\approx 25 \%$ ).

\subsection{Raman Spectra}

Raman spectra of HA-SRM in the range from $4000 \mathrm{~cm}^{-1}$ to $50 \mathrm{~cm}^{-1}$ recorded with relative intensities of 1 and 10 in the range below $1200 \mathrm{~cm}^{-1}$ and with relative intensity of 3.3 in the range above $1200 \mathrm{~cm}^{-1}$ are shown in Fig. 6. The spectra have the bands of hexagonal $\mathrm{HA}$ and two additional bands that arise from $\mathrm{HPO}_{4}{ }^{2-}$ impurity ions. Under the spectral resolution used (spectral slit width of $3.5 \mathrm{~cm}^{-1}$ ), no bands of monoclinic HA are resolved.

Bands of HA [26-29]: (a) The $3573 \mathrm{~cm}^{-1}$ and $329 \mathrm{~cm}^{-1}$ bands arise from stretching and translational modes of the $\mathrm{OH}^{-}$ions, respectively; the $\mathrm{OH}^{-}$librational bands expected in the $630 \mathrm{~cm}^{-1}$ region are not clearly detected although two bands are predicted by $\mathrm{C}_{6}$ factor group symmetry analysis [21]. (b) The $1076 \mathrm{~cm}^{-1}$, $1052 \mathrm{~cm}^{-1}$ (shoulder, sh), $1047 \mathrm{~cm}^{-1}, 1040 \mathrm{~cm}^{-1}$ (sh), and $1028.5 \mathrm{~cm}^{-1}$ bands arise from $v_{3} \mathrm{PO}_{4}$, the very strong $962 \mathrm{~cm}^{-1}$ band arises from $v_{1} \mathrm{PO}_{4}$, the $614 \mathrm{~cm}^{-1}$, $607 \mathrm{~cm}^{-1}, 590 \mathrm{~cm}^{-1}$, and $579 \mathrm{~cm}^{-1}$ bands arise from $v_{4} \mathrm{PO}_{4}$, and the $447 \mathrm{~cm}^{-1}$ and $431 \mathrm{~cm}^{-1}$ bands arise from $v_{2} \mathrm{PO}_{4}$. (c) The group of weak intensity bands in the $329 \mathrm{~cm}^{-1}$ to $50 \mathrm{~cm}^{-1}$ region derives from translations of the $\mathrm{Ca}^{2+}, \mathrm{PO}_{4}^{3-}$, and $\mathrm{OH}^{-}$ions and librations of the $\mathrm{PO}_{4}{ }^{3-}$ ions. The $329 \mathrm{~cm}^{-1}, 305 \mathrm{~cm}^{-1}$, and $270 \mathrm{~cm}^{-1}$ bands have been assigned to vibrations of the $2\left[\left(\mathrm{Ca}_{\mathrm{II}}\right)_{3}-(\mathrm{OH})\right]$ sublattice of hexagonal $\mathrm{HA}$, and the band at $285 \mathrm{~cm}^{-1}$ primarily to libratory phosphate motions $[28,30]$.

Bands of $\mathrm{CO}_{3}{ }^{2-}$ impurity ions: The strongest intensity $\mathrm{CO}_{3}$ band, $v_{1}$, for the B-type $\mathrm{CO}_{3}^{2-}$ impurity occurs at $1070 \mathrm{~cm}^{-1}$; this band is obscured by the strong intensi- 


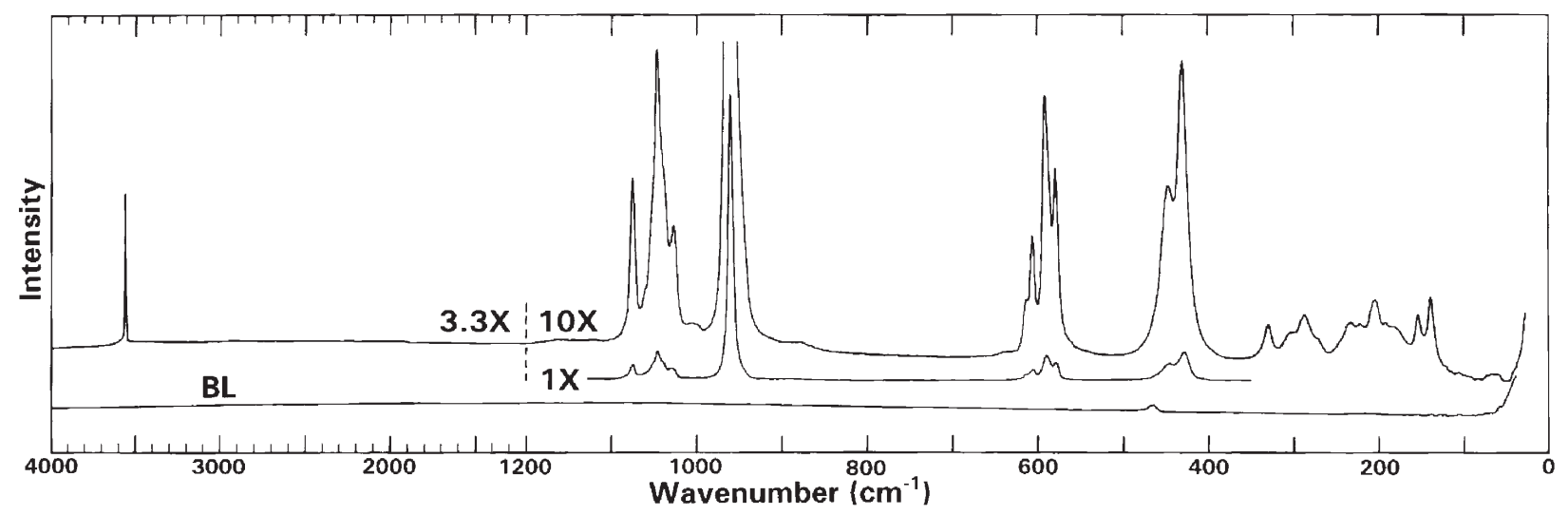

Fig. 6. Raman spectra of HA-SRM from $4000 \mathrm{~cm}^{-1}$ to $50 \mathrm{~cm}^{-1}$ recorded at relative intensities of 1 and 10 below $1200 \mathrm{~cm}^{-1}$ and 3.3 above 1200 $\mathrm{cm}^{-1}$. BL denotes the baseline.

ty $\mathrm{PO}_{4}$ band at $1076 \mathrm{~cm}^{-1}$. The other $\mathrm{CO}_{3}$ modes $v_{3}, v_{4}$, and $v_{2}\left(v_{2}\right.$ is expected to be Raman active because of low symmetry of $\mathrm{CO}_{3}{ }^{2-}$ ion) have band positions not obscured by the $\mathrm{PO}_{4}$ bands, but they have weak intensities and were not detected. The $v_{1} \mathrm{CO}_{3}$ band for A-type $\mathrm{CO}_{3}^{2-}$, unobscured by $\mathrm{PO}_{4}$ bands, occurs at $1106 \mathrm{~cm}^{-1}$ [31], and is useful for detecting the A-type $\mathrm{CO}_{3}{ }^{2-}$. However, this band was absent; this was expected because the IR spectra did not have bands for the A-type $\mathrm{CO}_{3}{ }^{2-}$.

Bands of $\mathrm{HPO}_{4}^{2-}$ impurity ions: The weak band at $1005 \mathrm{~cm}^{-1}$ is assigned to symmetric stretching of the $\mathrm{HPO}_{4}{ }^{2-}$ ions and the weak band at $880 \mathrm{~cm}^{-1}$ to $[\mathrm{P}-(\mathrm{OH})]$ stretching of the $\mathrm{HPO}_{4}{ }^{2-}$ ions [6,32]. Similarly as in IR spectra, these two Raman bands increase in intensity with an increase in $\mathrm{HPO}_{4}^{2-}$ content, and they are missing in spectra of HA-SRM that had been heated at $550{ }^{\circ} \mathrm{C}$ because of thermal conversion of $\mathrm{HPO}_{4}{ }^{2-}$ ions to $\mathrm{P}_{2} \mathrm{O}_{7}^{4}$ ions. This independent detection of $\mathrm{HPO}_{4}^{2-}$ ions in Raman spectra confirms the IR data on $\mathrm{HPO}_{4}{ }^{2-}$ ions.

Bands of silicate impurity ions: Bands of the trace silicate impurity, probably present as $\mathrm{SiO}_{3}{ }^{2-}$ or $\mathrm{Si}_{2} \mathrm{O}_{7}{ }^{6-}$ ions, were not detected because of the low silicate mass fractions (about $0.04 \%$ as $\mathrm{SiO}_{3}^{2-}$ or $\mathrm{Si}_{2} \mathrm{O}_{7}{ }^{6-}$ ions). The

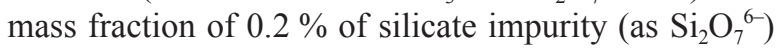
was detectable in other $\mathrm{HA}$ preparations by the $890 \mathrm{~cm}^{-1}$ band arising from $\mathrm{Si}_{2} \mathrm{O}_{7}^{6-}$ ions.

Bands of $\mathrm{H}_{2} \mathrm{O}$ molecules: Water vibrational modes give rise to weak intensity stretching and bending bands in Raman spectra. The water component in HA-SRM (mass fraction of $1.59 \%$ ) causes IR bands at $3700 \mathrm{~cm}^{-1}$ to $2500 \mathrm{~cm}^{-1}$ and $1630 \mathrm{~cm}^{-1}$; these water bands, expected at about the same wavenumbers in Raman spectra, were not observed in Raman spectra under the spectral intensity expansion used in Fig. 6.

\subsection{Combined Infrared and Raman Data}

A rigorous comparison of the number and coincidences of the IR and Raman bands cannot be made with the present data because equivalent high-resolution second derivative Raman spectra were not obtained for HA-SRM. Although additional Raman bands may be detected, comparisons of the predicted and observed current data are meaningful and are given in Table 4. IR and Raman bands that have wavenumber positions within $2 \mathrm{~cm}^{-1}$ were considered coincident.

The number and coincidence or noncoincidence of the infrared and Raman active bands predicted according to factor group analysis for the $v_{1}, v_{2}, v_{3}$, and $v_{4} \mathrm{PO}_{4}$ modes of HA having hexagonal structures $\left(\mathrm{P}_{3} / \mathrm{m}, \mathrm{C}_{6 \mathrm{~h}}\right)$ and $\left(\mathrm{P}_{3}, \mathrm{C}_{6}\right)$ [21] are given in Table 4 along with the observed number and coincidence or noncoincidence of the infrared and Raman bands of HA-SRM. Hexagonal HA belongs to the space group $\mathrm{P}_{3}$; if, however, the $\mathrm{OH}^{-}$ions are disregarded, the overall structure is $\mathrm{P}_{3} / \mathrm{m}$. The lower $\mathrm{P}_{3}$ symmetry results from the position, heteronuclearity, and order of the $\mathrm{OH}^{-}$ions. In fluoroapatite ( $\mathrm{P}_{3} / \mathrm{m}$ space group), the $\mathrm{F}$ ions are located along the $c$-axis on the mirror planes passing through the $\mathrm{Ca}_{\mathrm{II}}$ triangles, whereas in hexagonal $\mathrm{HA}$, the $\mathrm{OH}^{-}$ions, with internuclear axes coincident with the $c$-axis, are displaced about $0.03 \mathrm{~nm}$ from the planes of the $\mathrm{Ca}_{\mathrm{II}}$ triangles with protons pointing away from the $\mathrm{Ca}_{\text {II }}$ triangles [33]; thus, the mirror planes passing through the $\mathrm{Ca}_{\mathrm{II}}$ triangles are lost and the $\mathrm{P}_{3}$ space group results. These minor structural differences cause considerable differences in the vibrational selection rules.

A comparison of the predicted and observed spectral data for the $\mathrm{PO}_{4}$ modes in Table 4 shows a better fit with $\mathrm{C}_{6 \mathrm{~h}}$ than with $\mathrm{C}_{6}$ symmetry. Weights of $1,2,3$, and 3 were applied to data for the $v_{1}, v_{2}, v_{3}$, and $v_{4} \mathrm{PO}_{4}$ 
Table 4. Predicted number and coincidence or noncoincidence of infrared and Raman $v_{1}, v_{2}, v_{3}$, and $v_{4}$ bands for $\mathrm{PO}_{4}$ modes of hexagonal structures $\left(\mathrm{P}_{3} / \mathrm{m}, \mathrm{C}_{6 \mathrm{~h}}\right)$ and $\left(\mathrm{P}_{3}, \mathrm{C}_{6}\right)$ of calcium hydroxyapatite ${ }^{\mathrm{a}}$ and observed bands for HA-SRM

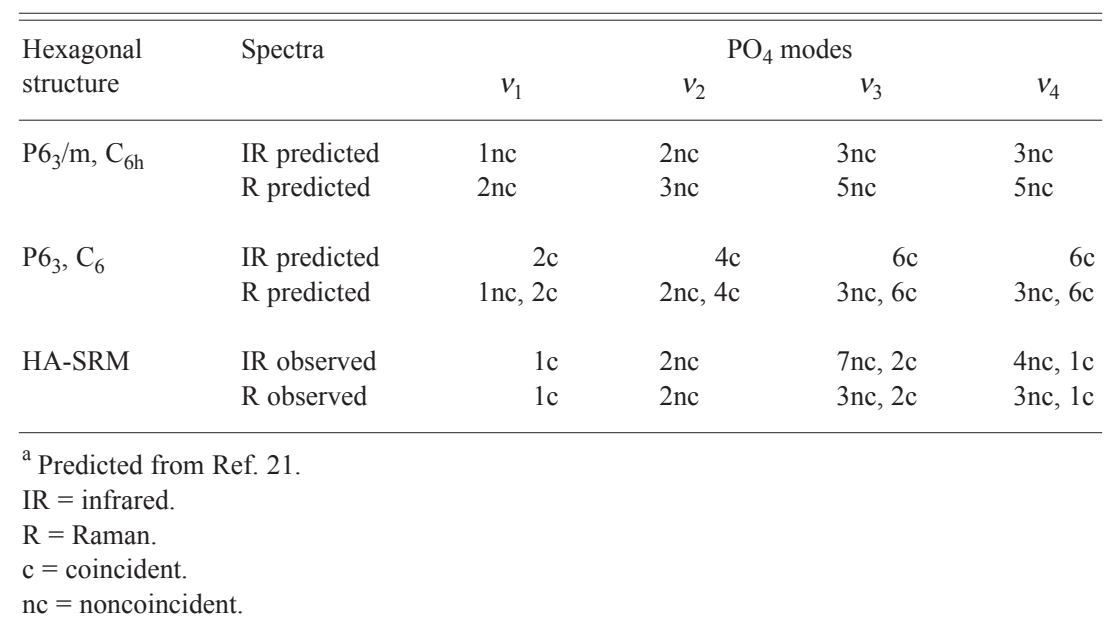

modes, respectively; these numerical weights correspond to the degeneracy of each mode. About $74 \%$ of the total spectral data for the $\mathrm{PO}_{4}$ modes (the total number of IR and Raman bands and the number of coincident/noncoincident bands) better fit with $\mathrm{C}_{6 \mathrm{~h}}$ symmetry. About $26 \%$ of the total spectral data for the $\mathrm{PO}_{4}$ modes (the total number of IR bands for the $v_{3}$ and $v_{4} \mathrm{PO}_{4}$ modes, the coincidence of the $v_{1}$ IR and Raman $\mathrm{PO}_{4}$ bands, and the coincidence/noncoincidence of the $v_{3}$ Raman bands) better fit with $\mathrm{C}_{6}$ symmetry. This better agreement with $\mathrm{C}_{6 \mathrm{~h}}$ symmetry is in accordance with previous conclusions based on fewer spectroscopic data $[21,26]$ that also favored $\mathrm{C}_{6 \mathrm{~h}}$ symmetry $\left(\mathrm{P}_{3} / \mathrm{m}\right.$ space group) for hexagonal HA.

The number of observed IR $v_{3}$ and $v_{4} \mathrm{PO}_{4}$ bands is larger than predicted for $\mathrm{C}_{6 \mathrm{~h}}$ symmetry. This is believed to derive from sources other than effects of lower $\mathrm{P}_{3}$ symmetry, and this will be considered in a separate paper [34].

\subsection{X-Ray Diffraction Pattern}

The XRD pattern of HA-SRM is shown in Fig. 7. The observed positions of diffraction lines $(2 \theta$ and corresponding $\left.d_{2 \theta}\right)$ and their relative intensities $\left(I_{\text {rel }}\right)$ are listed in Table 5. These $d_{2 \theta}$ and $I_{\text {rel }}$ for HA-SRM are in full agreement with the corresponding values reported for hexagonal HA (JCPDS, Card No. 9-432) [35]. The additional weak lines of monoclinic HA that have relative intensities less than $1 \%$ of the strongest hexagonal HA line were not observed at the intensity scale shown in Fig. 7. The additional XRD measurements, from

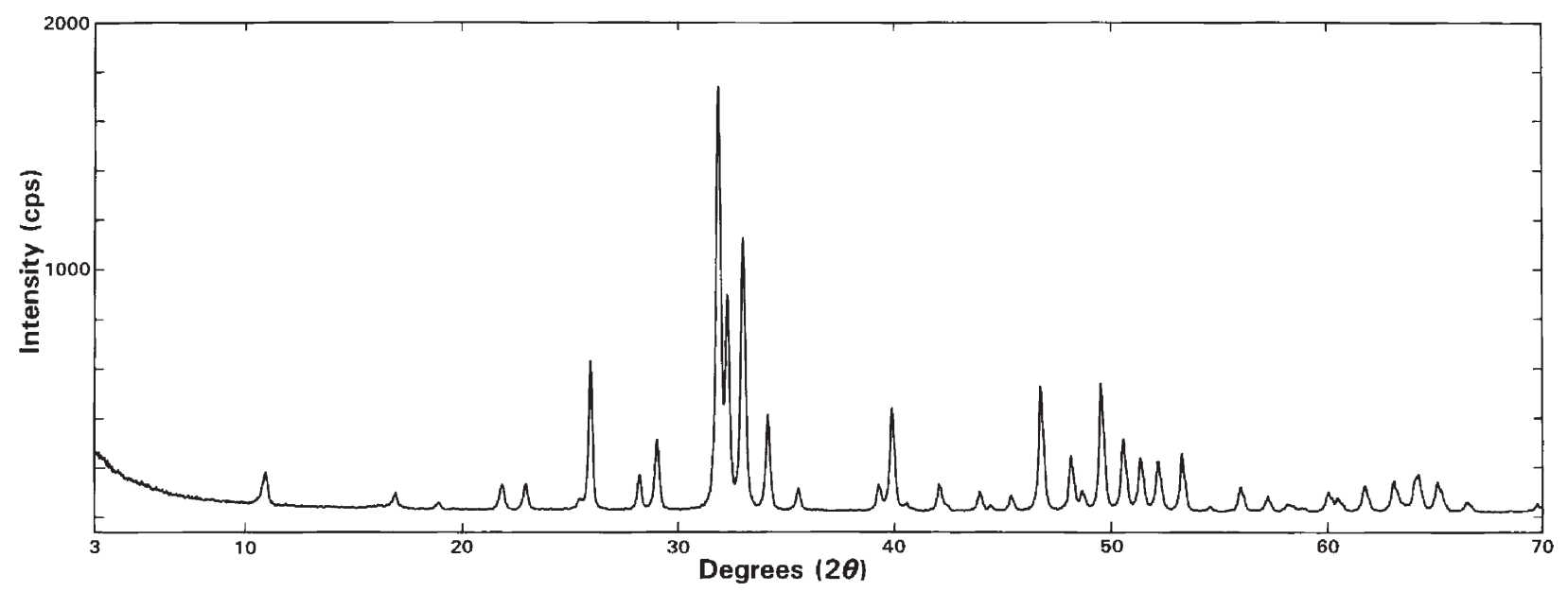

Fig. 7. X-ray diffraction pattern of HA-SRM in the $2 \theta$ range from $3^{\circ}$ to $70^{\circ}$. 
Table 5. $2 \theta$-values and relative intensities $\left(I_{\text {rel }}\right)$ observed from the XRD pattern of HA-SRM, $d$-values determined from $2 \theta$-values $\left(d_{2 \theta}\right)$, $d$-values calculated from unit cell parameters $\left(d_{\text {calc }}\right)$, and corresponding indices $(h k l)$

\begin{tabular}{|c|c|c|c|c|}
\hline $2 \theta\left(^{\circ}\right)$ & $d_{2 \theta}(\mathrm{nm})$ & $d_{\text {calc }}(\mathrm{nm})$ & $I_{\text {rel }}$ & $h k l$ \\
\hline 10.85 & 0.815 & 0.816 & 8 & 100 \\
\hline 16.87 & 0.525 & 0.526 & 3 & 101 \\
\hline 18.84 & 0.471 & 0.471 & 2 & 110 \\
\hline 21.75 & 0.408 & 0.408 & 6 & 200 \\
\hline 22.84 & 0.389 & 0.389 & 6 & 111 \\
\hline 25.35 & 0.351 & 0.351 & 2 & 201 \\
\hline 25.86 & 0.344 & 0.344 & 36 & 002 \\
\hline 28.11 & 0.317 & 0.317 & 8 & 102 \\
\hline 28.92 & 0.308 & 0.308 & 16 & 210 \\
\hline 31.77 & 0.281 & 0.281 & 100 & 211 \\
\hline 32.18 & 0.278 & 0.278 & 47 & 112 \\
\hline 32.90 & 0.272 & 0.272 & 65 & 300 \\
\hline 34.04 & 0.263 & 0.263 & 22 & 202 \\
\hline 35.44 & 0.253 & 0.253 & 5 & 301 \\
\hline 39.18 & 0.2297 & 0.2297 & 6 & 212 \\
\hline $39.793 *$ & 0.2263 & 0.2263 & 22 & 310 \\
\hline 40.43 & 0.2229 & 0.2229 & 1 & 221 \\
\hline 41.98 & 0.2150 & 0.2150 & 6 & 311 \\
\hline 42.30 & 0.2135 & 0.2134 & 1 & 302 \\
\hline 43.84 & 0.2063 & 0.2063 & 4 & 113 \\
\hline 44.36 & 0.2040 & 0.2040 & 1 & 400 \\
\hline 45.29 & 0.2000 & 0.2000 & 4 & 203 \\
\hline $46.683 *$ & 0.1944 & 0.1944 & 28 & 222 \\
\hline $48.068 *$ & 0.1891 & 0.1891 & 12 & 312 \\
\hline 48.58 & 0.1872 & 0.1872 & 3 & 320 \\
\hline $49.458 *$ & 0.1841 & 0.1841 & 30 & 213 \\
\hline $50.474 *$ & 0.1807 & 0.1807 & 15 & 321 \\
\hline $51.254^{*}$ & 0.1781 & 0.1781 & 11 & 410 \\
\hline $52.061 *$ & 0.1755 & 0.1755 & 11 & 402 \\
\hline $53.167 *$ & 0.1721 & 0.1721 & 14 & 004 \\
\hline 54.43 & 0.1684 & 0.1684 & 1 & 104 \\
\hline 55.85 & 0.1645 & 0.1645 & 6 & 322 \\
\hline 57.11 & 0.1611 & 0.1611 & 4 & 313 \\
\hline 58.03 & 0.1588 & 0.1588 & 2 & 501 \\
\hline 58.28 & 0.1582 & 0.1582 & 2 & 412 \\
\hline 58.74 & 0.1570 & 0.1570 & 1 & 330 \\
\hline 59.93 & 0.1542 & 0.1542 & 4 & 420 \\
\hline
\end{tabular}

* $2 \theta$-values have expanded uncertainty $(U)$ of $\pm 0.004^{\circ} 2 \theta(\mathrm{n}=4)$.

which a mass fraction of about $25 \%$ of monoclinic HA was determined in HA-SRM, will be reported in a separate paper [8].

\subsection{Unit-Cell Parameters}

The $a$ and $c$ unit-cell parameters for HA-SRM calculated from the eight selected diffraction lines $(2 \theta$-values marked with a in Table 5) are listed in Table 6. The complete set of $d$-values $\left(d_{\text {calc }}\right)$ calculated from these unitcell parameters is listed in Table 5. These $d_{\text {calc }}$-values are in excellent agreement with $d_{2 \theta^{-}}$-values determined from the $2 \theta$-values that were not used for unitcell parameters calculation ( $2 \theta$-values without asterisks in Table 5).
The $a$ and $c$ unit-cell parameters for HA-SRM determined in this paper are in very good agreement with the parameters determined for the same material by the Rietveld analyses $[5,36]$, given in Table 6 . The average values of these two independently determined unit-cell parameters for HA-SRM by the Rietveld analyses are: $a=0.94235 \mathrm{~nm}$, and $c=0.68852 \mathrm{~nm}$. As compared with these average unit-cell parameters, the values determined in this paper are $0.003 \%$ larger in $a$, and $0.003 \%$ larger in $c$ than the corresponding average values. The values for similarly prepared hexagonal HA [9] determined by the Rietveld analyses [37] (Table 6, HA-McDowell) are $0.065 \%$ smaller in $a$, and $0.001 \%$ larger in $c$ than the corresponding average values for HA-SRM determined by the Rietveld analyses.

\subsection{Crystallinity}

The mean angular widths at half-height (denoted as $B$ and $b$ ) for the (200), (002), (102), (210), (310), and (004) diffraction lines of HA-SRM ( $B$-values) and of hc-HA ( $b$-values) and the calculated $1 / \beta$ values are listed in Table 7 . The $1 / \beta$ values were determined in the next crystal directions: (i) along the $a$-axis perpendicular to $b$-c plane, $1 / \beta(200)=6.0\left({ }^{\circ} 2 \theta\right)^{-1} \pm 0.3\left({ }^{\circ} 2 \theta\right)^{-1}$, (ii) along the $c$-axis perpendicular to $a$ - $b$ plane, $1 / \beta(002)=8.4\left({ }^{\circ} 2 \theta\right)^{-1} \pm 0.2\left({ }^{\circ} 2 \theta\right)^{-1}$ and $1 / \beta(004)=$ $7.1\left({ }^{\circ} 2 \theta\right)^{-1} \pm 0.3\left({ }^{\circ} 2 \theta\right)^{-1}$, (iii) perpendicular to $c$-axis, $1 / \beta(210)=5.8\left({ }^{\circ} 2 \theta\right)^{-1} \pm 0.2\left({ }^{\circ} 2 \theta\right)^{-1}$ and $1 / \beta(310)=$ $5.5\left({ }^{\circ} 2 \theta\right)^{-1} \pm 0.2\left({ }^{\circ} 2 \theta\right)^{-1}$ and (iv) perpendicular to $b$ axis, $1 / \beta(102)=8.2\left({ }^{\circ} 2 \theta\right)^{-1} \pm 0.4\left({ }^{\circ} 2 \theta\right)^{-1}$. The bigger $1 / \beta$ value denotes the larger crystal size and lattice perfection in corresponding crystal directions showing for HA-SRM the biggest $1 / \beta$ values for size/strain in directions along $c$-axis and that perpendicular to $b$-axis, and the smallest $1 / \beta$ values for size/strain in directions along $a$-axis and those perpendicular to $c$-axis. The $1 / \beta(002)$ for HA-SRM is $\approx 10 \%$ smaller and $1 / \beta(310)$ for HA-SRM is $\approx 40 \%$ larger than corresponding values for HA prepared by DCPA hydrolysis at $\mathrm{pH} \approx 6.5$ [38]. For HA-SRM the ratio of $1 / \beta(002)$ and $1 / \beta(310)$ values, $R(1 / \beta)=[1 / \beta(002)] /[1 / \beta(310)]=$ $\beta(310) / \beta(002)$, is 1.6 and for HA hydrolyzed from DCPA at $\mathrm{pH} \approx 6.5$ the ratio $R(1 / \beta)$ is 2.5 [38]. These $R(1 / \beta)$-values can be correlated with the ratio of crystal height (longer dimension) and crystal width (shorter dimension) of these HA crystals determined microscopically. HA-SRM crystals for which $R(1 / \beta)=1.6$ have cylindrical shape with the height/diameter ratio of $\approx 2$ (Fig. 2), and HA crystals hydrolyzed from DCPA, for which $R(1 / \beta)=2.5$, have plate-like shape with very large height/width ratio of $\approx 10$ [38]. It indicates that the 
Table 6. Unit-cell parameters for HA-SRM and similarly prepared HA by McDowell et al. [9]

\begin{tabular}{llll}
\hline \hline \multicolumn{1}{c}{ Sample } & \multicolumn{1}{c}{$a(\mathrm{~nm})$} & $c(\mathrm{~nm})$ & XRD analysis \\
\hline HA-SRM & $0.94238 \pm 0.00009^{\mathrm{a}}$ & $0.68854 \pm 0.00006^{\mathrm{a}}$ & Standard \\
HA-SRM & $0.942253 \pm 0.000013^{\mathrm{a}}$ & $0.688501 \pm 0.000009^{\mathrm{a}}$ & This paper \\
HA-SRM & $0.94244 \pm 0.00002^{\mathrm{b}}$ & $0.68854 \pm 0.00002^{\mathrm{b}}$ & Rietveld \\
HA-McDowell & $0.94174 \pm 0.00002^{\mathrm{b}}$ & $0.68853 \pm 0.00002^{\mathrm{b}}$ & Rietveld \\
\hline
\end{tabular}

\footnotetext{
${ }^{\text {a }}$ Mean value \pm expanded uncertainty $(U)$.

${ }^{\mathrm{b}}$ Mean value \pm standard deviation.
}

Table 7. The line width at half-height ( $B$-value) for selected XRD lines of HA-SRM, the corresponding line width at half-height $(b-$ value) of hc-HA ${ }^{\mathrm{a}}$, and calculated $1 / \beta$ values

\begin{tabular}{cccc}
\hline \hline$h k l$ & $B\left({ }^{\circ} 2 \theta\right)$ & $\mathrm{b}\left({ }^{\circ} 2 \theta\right)$ & $1 / \beta\left({ }^{\circ} 2 \theta\right)^{-1}$ \\
\hline 200 & $0.225 \pm 0.007$ & $0.150 \pm 0.002$ & $6.0 \pm 0.3$ \\
002 & $0.188 \pm 0.002$ & $0.145 \pm 0.002$ & $8.4 \pm 0.2$ \\
102 & $0.183 \pm 0.005$ & $0.136 \pm 0.004$ & $8.2 \pm 0.4$ \\
210 & $0.218 \pm 0.003$ & $0.134 \pm 0.003$ & $5.8 \pm 0.2$ \\
310 & $0.218 \pm 0.004$ & $0.120 \pm 0.004$ & $5.5 \pm 0.2$ \\
004 & $0.181 \pm 0.005$ & $0.114 \pm 0.003$ & $7.1 \pm 0.3$ \\
\hline
\end{tabular}

${ }^{\text {a }}$ Highly crystalline HA prepared by solid state thermal reaction [17].

$c$-axis of these HA crystals is in the direction along the crystal height and the $a$-axis is in the direction along the crystal width.

\subsection{Solubility}

The solubility product of this HA-SRM was previously determined [4]. The saturated solutions with respect to HA-SRM were obtained by dissolution of HA-SRM crystals in aqueous solutions of phosphoric acid for $60 \mathrm{~d}$ at $37.0^{\circ} \mathrm{C} \pm 0.1{ }^{\circ} \mathrm{C}$. The thermodynamic solubility product, $K_{\mathrm{sp}}$, of HA-SRM defined as $K_{\text {sp }}(\mathrm{HA})=a^{5}\left(\mathrm{Ca}^{2+}\right) a^{3}\left(\mathrm{PO}_{4}^{3-}\right) a\left(\mathrm{OH}^{-}\right)$, where $a$ denotes ion activity, was calculated from measured equilibrium calcium and phosphate concentrations and $\mathrm{pH}$ values as input data. The mean value and standard uncertainty, $u_{\mathrm{i}}$, of the twelve replicate determinations $(n=12)$ was $K_{\text {sp }}(\mathrm{HA})=(2.03 \pm 0.04) \times 10^{-59}$. The standard uncertainties, $u_{i}(y)$, derived from other sources were also determined. These other sources were uncertainties in measurements of $\mathrm{Ca}, \mathrm{P}$ and $\mathrm{pH}$, and uncertainties in dissociation constants of phosphoric acid $\left(K_{1}, K_{2}\right.$, and $\left.K_{3}\right)$ and stability constant of calcium phosphate complexes used for $K_{\mathrm{sp}}$ calculation. The major contributions to the combined uncertainty, $u_{\mathrm{c}}=0.356 \times 10^{-59}$, were from $\mathrm{pH}$ measurements $\left(u_{i}=0.196\right)$ and the $K_{3}$ literature value $\left(u_{i}=0.280\right)$. The expanded uncertainty, $U=2 u_{\mathrm{c}}$, was
$0.71 \times 10^{-59}$; thus, the thermodynamic $K_{\mathrm{sp}}(\mathrm{HA})$ at $37{ }^{\circ} \mathrm{C}$, expressed as the mean $\pm U$, was $(2.03 \pm 0.71) \times$ $10^{-59}$ and its $\mathrm{p} K_{\mathrm{sp}}(\mathrm{HA})$ was $58.69 \pm 0.15$. This $K_{\mathrm{sp}}(\mathrm{HA})$ value of $(2.03 \pm 0.71) \times 10^{-59}$ is in very good agreement with the literature value of $(2.36 \pm 0.28) \times 10^{-59}$ determined under similar conditions for similarly prepared HA [9].

\section{Conclusions}

The chemical and physical analyses of this HA-SRM are considered very reliable based on the consistency of the combined results. This HA-SRM has application as a standard of numerous well established chemical and physical properties to compare with and to establish the validity of equivalent analyses on natural and synthetic hydroxyapatites, the mineral phases in calcified tissues, and in testing and regulation.

\section{Acknowledgment}

This work was supported in part by the ADAF, the FDA, NIST, and the NIH/NIDCR Grant DE11789. We thank R. G. Garvey, North Dakota State University, for the LSUCRIPC program, M. D. McKee, University of Toronto, for transmission electron micrographs of the crystals, and W. E. Roberts, NIST, for thermogravimetric analyses.

\section{References}

[1] R. Z. LeGeros, Calcium Phosphates in Oral Biology, Karger, Basel (1991).

[2] J. C. Elliott, Structure and Chemistry of the Apatites and Other Calcium Orthophosphates, Elsevier, Amsterdam (1994).

[3] J. Arends, J. Christoffersen, M. R. Christoffersen, H. Eckert, B. O. Fowler, J. C. Heughebaert, G. H. Nancollas, J. P. Yesinowski, and S. J. Zawacki, A Calcium Hydroxyapatite Precipitated from an Aqueous Solution. An International Multimethod Analysis, J. Crystal Growth 84, 515-532 (1987). 
[4] M. Markovic, B. O. Fowler, M. S. Tung, and E. S. Lagergren, Composition and Solubility Product of a Synthetic Calcium Hydroxyapatite. Chemical and Thermal Determination of $\mathrm{Ca} / \mathrm{P}$ Ratio and Statistical Analysis of Chemical and Solubility Data, In: Mineral and Scale Formation, Proc. of ACS Symposium, Z. Amjad, ed., Plenum, New York (1995) pp. 271-282.

[5] Certificate of Analysis, Standard Reference Material 2910, National Institute of Standards and Technology, Gaithersburg, MD, USA (1997).

[6] B. O. Fowler, unpublished data.

[7] J. C. Elliott and P .E. Mackie, Monoclinic Hydroxyapatite, In: Physico-chimie et Cristallographie des Apatites d'Interet Biologique-No 230, Centre National de la Recherche Scientifique (C.N.R.S.), Paris, 69-76 (1975).

[8] M. Markovic, B. O. Fowler, and M. S. Tung, Preparation and Characterization of Monoclinic Calcium Hydroxyapatite, in preparation.

[9] H. McDowell, T. M. Gregory, and W. E. Brown, Solubility of $\mathrm{Ca}_{5}\left(\mathrm{PO}_{4}\right)_{3} \mathrm{OH}$ in the System $\mathrm{Ca}(\mathrm{OH})_{2}-\mathrm{H}_{3} \mathrm{PO}_{4}-\mathrm{H}_{2} \mathrm{O}$ at $5,15,25$ and $37^{\circ} \mathrm{C}$, J. Res. Natl. Bur. Stand. (U.S.) 81A, 273-281 (1977).

[10] M. Markovic, B. O. Fowler, and W. E. Brown, Octacalcium Phosphate Carboxylates. 2. Characterization and Structural Considerations, Chem. Mater. 5, 1406-1416 (1993).

[11] A. Gee and V. R. Deitz, Determination of Phosphate by Differential Spectrophotometry, Anal. Chem. 25, 1320-1324 (1953).

[12] A. Gee and V. R. Deitz, Pyrophosphate Formation upon Ignition of Precipitated Basic Calcium Phosphates, J. Am. Chem. Soc. 77, 2961-2965 (1955).

[13] S. Brunauer, P. H. Emmett, and E. Teller, Adsorption of Gases in Multimolecular Layers, J. Am. Chem. Soc. 60, 309-319 (1938).

[14] R. N. Jones and A. Nadeau, Further Observations on the Use of Indene for the Wavenumber Calibration of Infrared Spectrometers, Spectrochim. Acta 20, 1175-1183 (1964).

[15] J. Loader, Chap. 3 in Basic Laser Raman Spectroscopy, Heyden, London (1970).

[16] H. P. Klug and L. E. Alexander, X-ray Diffraction Procedures for Polycrystalline and Amorphous Materials, 2nd Ed., John Wiley and Sons, New York (1974) pp. 618-708.

[17] B. O. Fowler, Infrared Studies of Apatites. II. Preparation of Normal and Isotopically Substituted Calcium, Strontium, and Barium Hydroxyapatites and Spectrastructurecomposition Correlations, Inorg. Chem. 13, 207-214 (1974).

[18] Guide to the Expression of Uncertainty in Measurement, ISBN 92-67-10188-9, 1st Ed., ISO, Switzerland (1993).

[19] H. H. Ku, Notes on the Propagation of Error Formulas, J. Res. Natl. Bur. Stand. (U.S.) 70C, 263-273 (1966).

[20] H. M. Rootare and R. G. Craig, Vapor Phase Adsorption of Water on Hydroxyapatite, J. Dent. Res. 56(12), 1437-1488 (1977).

[21] B. O. Fowler, Infrared Studies of Apatites. I. Vibrational Assignments for Calcium, Strontium, and Barium Hydroxyapatites Utilizing Isotopic Substitution, Inorg. Chem. 13, 194-207 (1974).

[22] D. W. Holcomb and R. A. Young, Thermal Decomposition of Human Tooth Enamel, Calcif. Tissue Int. 31,189-201 (1980).

[23] J. C. Elliott, The Crystallographic Structure of Dental Enamel and Related Apatites, PhD. Thesis, University of London (1974).

[24] E. E. Berry, The Structure and Composition of Some Calciumdeficient Apatites, J. Inorg. Nucl. Chem. 29, 317-327 (1967).
[25] S. J. Joris and C. H. Amberg, The Nature of Deficiency in Nonstoichiometric Hydroxyapatites. II. Spectroscopic Studies of Calcium and Strontium Hydroxyapatites, J. Phys. Chem. 75(20), 3172-3178 (1971).

[26] K. C. Blakeslee and R. A. Condrate, Sr., Vibrational Spectra of Hydrothermally Prepared Hydroxyapatites, J. Amer. Ceram. Soc. 54(11), 559-563 (1971).

[27] D. C. O'Shea, M. L. Bartlett, and R. A. Young, Compositional Analysis of Apatites with Laser-Raman Spectroscopy: (OH, F, Cl) Apatites, Archs. Oral Biol. 19, 995-1006 (1974).

[28] B. O. Fowler, Raman and Infrared Vibrational Spectra of Apatites, Mineralized Tissue Research Communications 1, Abstract No. 129 (1975). (Copy available from B. O. Fowler).

[29] D. G. A. Nelson and B. E. Williamson, Low-temperature Laser Raman Spectroscopy of Synthetic Carbonated Apatites and Dental Enamel, Austral. J. Chem. 35, $715-727$ (1982).

[30] B. O. Fowler, Polarized Raman Spectra of Apatites, J. Dent. Res. 56, Abstract No. 68 (1977).

[31] B. O. Fowler, I. Polarized Raman Spectra of Apatites. II. Raman Bands of Carbonate Ions in Human Tooth Enamel, Mineralized Tissue Research Communications 3, Abstract No. 68 (1977). (Copy available from B. O. Fowler).

[32] B. O. Fowler, M. Markovic, and W. E. Brown, Octacalcium Phosphate. 3. Infrared and Raman Vibrational Spectra, Chem. Mater. 5, 1417-1423 (1993).

[33] M. I. Kay, R. A. Young, and A. S. Posner, Crystal Structure of Hydroxyapatite, Nature 204, 1050-1052 (1964).

[34] B. O. Fowler, Second Derivative Vibrational Spectra of Fluoroapatite and Hexagonal and Monoclinic Hydroxyapatite, in preparation.

[35] Powder Diffraction File: Inorganic Phases, Joint Committee on Powder Diffraction Standards, Swarthmore (1986) Card No. 9432.

[36] H. Morgan, R. M. Wilson, J. C. Elliott, S. E. P. Dowker, and P. Anderson, Preparation and Characterization of Monoclinic Hydroxyapatite and its Precipitated Carbonate Apatite Intermediate, Biomaterials 21, 617-627 (2000).

[37] R. A. Young and D. W. Holcomb, Variability of Hydroxyapatite Preparations, Calcif. Tissue Int. 34, 517- 532 (1982).

[38] K. Ishikawa and E. D. Eanes, The Hydrolysis of Anhydrous Dicalcium Phosphate into Hydroxyapatite, J. Dent. Res. 72(2), 474-480 (1993)

About the authors: Milenko Markovic and Ming S. Tung are PhD chemists with the American Dental Association Foundation in the Paffenbarger Research Center at NIST, and Bruce O. Fowler was a research chemist with the National Institute of Dental and Craniofacial Research's Research Associate Program in the Dental and Medical Materials Group, Polymers Division, Material Science and Engineering Laboratory at NIST and is now a guest researcher in the Polymers Division, Material Science and Engineering Laboratory at NIST. The National Institute of Standards and Technology is an agency of the Technology Administration, U.S. Department of Commerce. 